\title{
Reduction in the Corrosion Rate of Magnesium and Magnesium Alloy Specimens and Implications for Plain Fully Bioresorbable Coronary Artery Stents: A Review
}

\author{
Gladius Lewis \\ Department of Mechanical Engineering, The University of Memphis, Memphis, USA \\ Email: glewis@memphis.edu
}

How to cite this paper: Lewis, G. (2016) Reduction in the Corrosion Rate of Magnesium and Magnesium Alloy Specimens and Implications for Plain Fully Bioresorbable Coronary Artery Stents: A Review. World Journal of Engineering and Technology, 4, 572-597.

http://dx.doi.org/10.4236/wjet.2016.44055

Received: August 15, 2016

Accepted: November 6, 2016

Published: November 9, 2016

Copyright $\odot 2016$ by authors and Scientific Research Publishing Inc. This work is licensed under the Creative Commons Attribution International License (CC BY 4.0).

http://creativecommons.org/licenses/by/4.0/

\section{(c) (i) Open Access}

\begin{abstract}
The most popular treatment/management modality for coronary artery disease, which is one of the leading causes of death, is percutaneous transluminal coronary intervention (popularly known as "plain old balloon angioplasty") followed by implantation of a stent ("stenting"). Stent types have evolved from bare metal stents through first-generation drug-eluting stents to fully bioresorbable stents (FBRSs). Two examples of FBRSs are 1) Mg scaffold with no coating; and 2) Mg alloy scaffold coated with a bioresorbable polymer in which an anti-proliferative drug is embedded. In the case of $\mathrm{Mg} / \mathrm{Mg}$ alloy FBRSs, one of the reported clinical results is that the resorption time of the stent is too short $(<\sim 4 \mathrm{mo}$ to $\sim 12 \mathrm{mo}$ ), a consequence of the high corrosion rate of the metal/alloy. The present review article contains 1 ) a summarized but comprehensive comparison and contrast of all the types of stents, with special reference to $\mathrm{Mg} / \mathrm{Mg}$ alloy FBRSs; 2) a critical review of the body of literature on methods to reduce the corrosion rate of $\mathrm{Mg} / \mathrm{Mg}$ alloy specimens in various aqueous biosimulating media that may have implications for plain $\mathrm{Mg} / \mathrm{Mg}$ alloy FBRSs, examples of such methods being alloy chemistry modification and fabrication using a nanocomposite; and 3) directions for future work on $\mathrm{Mg} / \mathrm{Mg}$ alloy FBRSs that draw upon the findings highlighted in item (2) above as well as on other ideas, such as utilization of a Mg matrix composite and fabrication using a metal additive manufacturing method. Thus, information given in this review may find use in work on decreasing the in vivo resorption time (and, hence, improving the clinical efficacy) of the current generation of fully-bioresorbable $\mathrm{Mg} / \mathrm{Mg}$-alloy stents as well as guide the development of the next generation of these stents.
\end{abstract}

\section{Keywords}

Coronary Artery Disease, Fully Bioresorbable Stents (FBRSs) 


\section{Introduction}

Coronary artery disease (CAD) (sometimes called coronary heart disease or ischemic heart disease), the most common of the cardiovascular diseases, is caused by atherosclerosis, the genesis of which is damage to the endothelium [1]. A large array of factors has been identified as contributing to or causing atherosclerosis, including hypertension, Type II diabetes, smoking, high level of cholesterol in the blood, and genetic polymorphisms (such as angiotensin converting enzyme and interleukin-1 receptor antagonist) [2]. Flow of cholesterol-containing blood, via low-density lipoproteins, over the damaged site in the artery initiates a cascade of events (including, in particular, accumulation of fat and lipids in the blood) that culminate in the formation of de-novo lesions (plaque) at the site [1] [2] (Figure 1). With time, the plaque enlarges (that is, the artery is narrowed), thereby blocking the smooth flow of blood, and, hence, weakening the artery. Most importantly, plaque is unstable, and, as such, may rupture, causing a blood clot to occur, with the result being myocardial infarction (a heart attack) and, sometimes, death [1] [2].

CAD is one of the leading causes of death, accounting for the death of about 371,000 people in the United States (about 1 in 7 deaths) [3] and about 8 million people in the

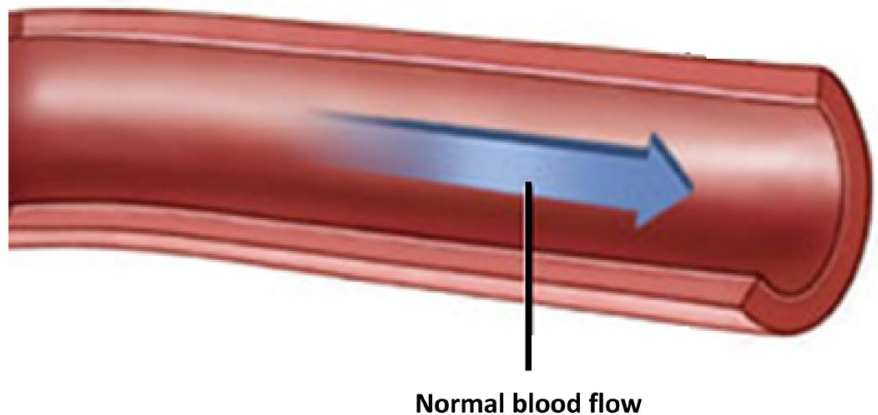

(a)

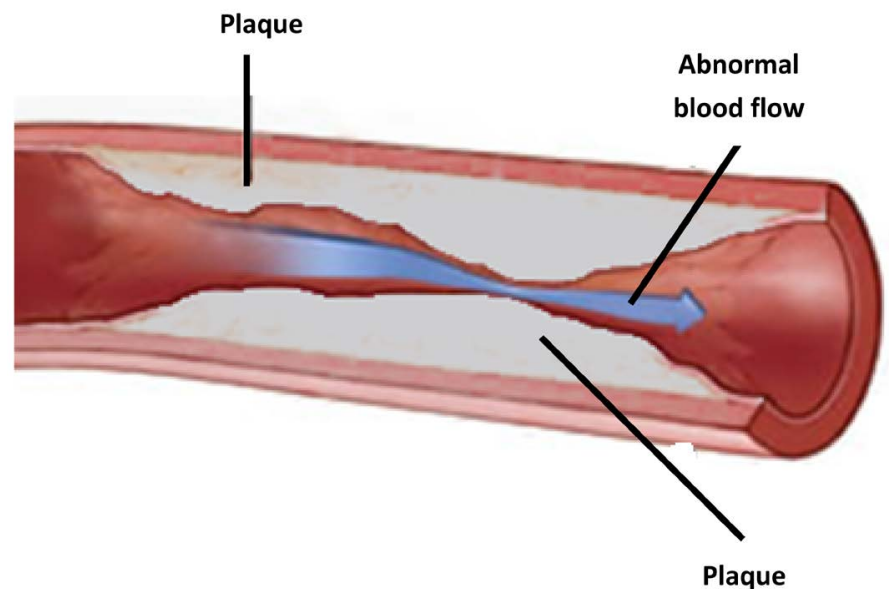

(b)

Figure 1. Schematic drawings of a segment of a coronary artery: normal artery (no plaque) (a) and atherosclerotic artery (with plaque) (b). 
world (between 1 in 6 and 1 in 3 deaths) each year [4]. The incidence of death due to CAD varies widely, with it being very low in some countries (such as France, Japan, Japan, and South Korea), moderate in others (such as the Indonesia, Thailand, and the United States), high in others (such as Laos, Malaysia, and Sri Lanka), and very high in others (such as Russia, Turkmenistan, and Ukraine) [5]. Furthermore, within a country, such as the United States, the age-adjusted CAD mortality rate death varies with 1 ) geographical location (state/province/region) [6]; and 2) time (the annual decline in this rate dropped from $3.79 \%$ for the period 2000 to 2011 to $0.95 \%$ for 2011 to 2014 [7]. The economic burden for CAD mortality and morbidity is very high; for example, in the United States, direct expenditures (for example, prescription drug costs) and indirect annual expenditures (for example, lost productivity) are estimated to be about $\$ 88 \mathrm{~b}$ and $\$ 67 \mathrm{~b}$, respectively [8].

The current modalities for the treatment/management of CAD may be grouped into two broad categories, namely, evidence-based medical therapy and percutaneous coronary intervention (PTCI) (surgical intervention) [9]-[12]. Within the latter category, there are myriad options, such as coronary artery bypass grafting (CABG) (of which there are several variants, such as conventional (pump); off-pump, and combination of the off-pump and minimally-invasive direct CABG techniques (MIDCAB)); percutaneous transluminal coronary angioplasty using a plain balloon ("balloon angioplasty"); balloon angioplasty using a balloon coated with an anti-proliferative drug (APD) (BCA); balloon angioplasty followed by the placement of a stent ("percutaneous coronary intervention or "stenting"); atherectomy (use of a catheter-deliverable tool to debulk and remove the plaque by cutting, shaving, sanding, or vaporization); and combination/hybrid procedures; for example, MIDCAB and stenting, atherectomy followed by balloon angioplasty, and atherectomy followed by APD [9] [13]-[24]. The choice of modality for a given case is very challenging because it is dictated by a large array of factors, in particular, stage of CAD (for example, stable CAD and acute myocardial infraction), demographic characteristics and health status of the patient (principally, age and comorbidities, such as diabetes mellitus and high risk for bleeding), location of the lesion in the artery (for example, on a curve or immediately followed by a curve or at the left main stem); type of lesion (such as plain single-vessel, bifurcation single-vessel, plain multi-vessel, and calcified lesions); size of the artery (for example, $<$ or $>3 \mathrm{~mm}$ ); degree of occlusion/blockage of the artery (that is, ratio of lesion size to artery size); and presence or absence of ancillary cardiovascular conditions (for example, myocardial infarction, saphenous vein graft disease and diffuse disease requiring 4 ormore stents) [25] [26] [27]. This challenge is manifest in the fact that, in spite of a voluminous body of literature comprising randomized controlled trials (RCTs), systematic review of results of RCTs, and meta-analyses of the results of RCTs in which the subject is either one modality or two or more [21] [28] [29] [30], there is a lack/shortage of evidencebased recommendations. This has led to guidelines; for example, in 2014, the European Society of Cardiology listedpolymer-coated drug-eluting stents and BCA as preferred procedures [30] and European and US guidelines call for the use of a "Heart Team" 
(comprising clinical cardiologists(s), interventional cardiologist(s), and cardiothoracic surgeon(s)) in making a decision on modality to use for a particular case [15]. Taking into account the variety of clinical cases seen, the most widely used modality is stenting [25].

Stent types have evolved from bare metal stents (introduced in 1987) through durable polymer-coated drug-eluting stents (introduced in 2004) to plain or coated fully bioresorbable stents (FBRSs) (introduced in 2010) (Figure 2) [32]. In a plain FBRS, the scaffold is made of $\mathrm{Mg}$ or a $\mathrm{Mg}$ alloy, whereas, in a coated FBRS, the scaffold, made of either a $\mathrm{Mg}$ alloy or a bioresorbable polymer, is coated with a bioresorbable polymer in which an anti-proliferative drug is embedded. There is a growing body of reviews of the literature on bioresorbable stents exclusively [33]-[43], but only very few cover $\mathrm{Mg} / \mathrm{Mg}$ alloy FBRSs and, of these, fewer still include any coverage of what, arguably, is the most important shortcoming/challenge of this type of stent, which is high corrosion rate (resulting in rapid resorption) [33] [34] [35] [36]. However, 1) in the review by Boland et al. [33], the subject is degradation models for both metallic and polymeric components and their application to both Mg-based and polymer-based bioresorbable stents; 2) in the review by Ma et al. [34], the subject is coatings for both Mg-based bioresorbable stents and orthopaedic implants and only a minimal reference to corrosion is made; and 3) the review by Uddin et al. [35] focused on surface treatments for controlling the corrosion of $\mathrm{Mg}$ and $\mathrm{Mg}$-based alloys for applications in orthopaedics and cardiovascular stenting; and 4) the review by Hornberger et al. [36] is on coatings for biomedical applications and not on stents per se and the coverage on corrosion is short.

The present work concentrates exclusively on a review of the literature on methods to improve decrease the corrosion rate of $\mathrm{Mg}$ and $\mathrm{Mg}$ alloy specimens in aqueous biosimulating media. Results from these literature studies may inform choice of materials, fabrication method, and processing method of the next generation of $\mathrm{Mg} / \mathrm{Mg}$ alloy FBRSs, which may translate to slower resorbability (that is, improved clinical efficacy). The remainder of the review is organized in five sections. In the first, Stent Types and Clinical Performance, features of all stent types and the major clinical events that

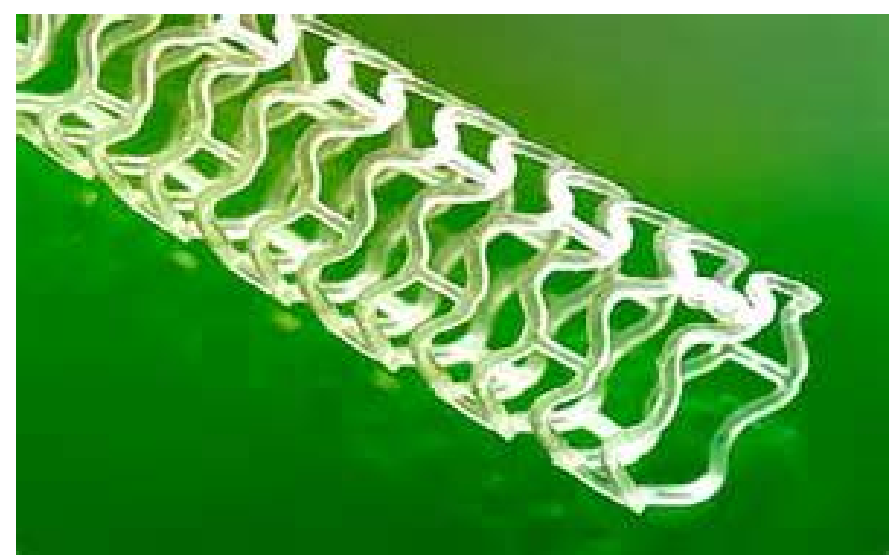

Figure 2. Aphotograpgh of the ABSORB BVS fully bioresorbable coronary artery stent. (Reprinted with permission from Abbott Vascular System, Santa Clara, CA, USA). 
each type elicits are presented. There are three reasons for including this section. The first was to present a compact but comprehensive summary of all the theoretical advantages and shortcomings of all the various types of stents, since this kind of summary is very scare in the literature [32]. The second was to highlight the motivation for introduction of a FBRS and to compare and contrast it vis a visa durable stent. The third was to summarize results on the clinical performance of FBRSs, underscoring the state-of-the-art nature of the present work because the aforementioned results have only recently been presented in the literature. The focus of the second section, Approaches to Increase Resorption Time, is methods that have been investigated for reducing the corrosion rate of $\mathrm{Mg}$ and its alloys in aqueous biosimulating media. These methods may be applicable to plain fully bioresorbable $\mathrm{Mg} / \mathrm{Mgalloy}$ stents; that is, stents in which there is no coating. The third section, Appraisal of Approaches, contains a critical appraisal of the approaches discussed in the second section, with a view to identifying the methods that lead to the largest decrease in corrosion rate. In the fourth section, Potential Future Research Areas, additional methods that have a potential to be used to reduce the corrosion rate of $\mathrm{Mg}$ and $\mathrm{Mg}$ alloys for use in fabricating FBRSs are covered. Thus, information given in the third and fourth sections have the potential to be used to improve the clinical efficacy of the current generation of these stents as well as to ensure improved resorbability of the next generation. The fifth section, Summary, contains a summary of the key points made in the review.

\section{Stent Types and Their Clinical Performance}

\subsection{Categorization Schemes}

There is a multitude of stent types available for clinical use. From a taxonomical perspective, they may be grouped in several different ways. For example, on the basis of design (slotted tubular, open-celled, closed-cell, and modular types), cross-sectional shape (for example, round struts type), strut thickness, strut/artery coverage, and materials used for the different parts.

On the basis of the lattermost-mentioned characteristic, five broad types are recognized, these being durable, non-drug-eluting (sometimes called "bare metal stents" (BMSs)); durable, polymer-coated, drug-eluting (sometimes, called "drug-eluting stents" (DESs)); partially bioresorbable, drug-eluting (sometimes, simply called "partially bioresorbable stents (PBRSs); fully bioresorbable, non-drug-eluting; and fully bioresorbable, drug-eluting [29] [30] [38] [40] [41] [42] [44] [45] [46]. Within each of these categories, there are sub-types depending on characteristics such as scaffold material (metal or polymer), coating material (polymer or non-polymer), and drug eluted (for example, biolimus, everolimus, paclitaxel, or sirolimus) (Table 1).

The clinical consensus is that a stent is only needed during the vascular healing period after it is placed in the artery. Thus, using the long-term in vivo effects of a stent as the basis for categorization leads to two types: durable (any variant of BMS or DES) and bioresorbable. A durable stent is undesirable because in the post-healing period, among other things, it delays endothelialization, instigates vascular inflammation, precipitates 
Table 1. Some features of examples of types of coronary arterystents ${ }^{\mathrm{a}, \mathrm{b}}$.

\begin{tabular}{|c|c|c|c|c|c|}
\hline Type & Scaffold material & $\begin{array}{c}\text { State of surface } \\
\text { of scaffold }\end{array}$ & $\begin{array}{c}\text { Coating } \\
\text { on scaffold }\end{array}$ & $\begin{array}{l}\text { Drug in } \\
\text { coating }\end{array}$ & $\begin{array}{c}\text { Example } \\
\text { (Commercial name) }\end{array}$ \\
\hline \multirow{2}{*}{$\begin{array}{l}\text { Durable non-drug- } \\
\text { eluting bare metal } \\
\text { stent (BMS) }\end{array}$} & Durable metal & Plain & None & None & \\
\hline & $\begin{array}{c}\text {--Co-Cr } \\
--316 \text { stainlesssteel } \\
\text {--Pt-Cr } \\
\text {--Nitinol }\end{array}$ & & & & $\begin{array}{c}\text { Driver MP35N } \\
\text { Omega }\end{array}$ \\
\hline $\begin{array}{l}\text { Durablenon-drug-eluting } \\
\text { coated metal stent } \\
\text { (CMS-I) }\end{array}$ & Durable metal & Plain & $\begin{array}{c}\text { Yes } \\
\text { Diamond-like coating } \\
\text { or } \mathrm{IrO} \text {, or } \mathrm{TiN} \text {, or } \mathrm{SiC} \\
\text { coating }\end{array}$ & None & Titan \\
\hline \multirow[t]{2}{*}{$\begin{array}{c}\text { Durable antigen/ } \\
\text { inhibitor-eluting } \\
\text { coated metalstent } \\
\text { (CMS-II) }\end{array}$} & Durable metal & Plain & Yes & $\begin{array}{c}\text { Yes, butdrug is a } \\
\text { non-pharmacological } \\
\text { agent }\end{array}$ & \\
\hline & & & $\begin{array}{c}\text { A polysaccharide } \\
\text { matrix that contains } \\
\text { anti-human CD34 antigen }\end{array}$ & & Genous \\
\hline \multirow[t]{5}{*}{$\begin{array}{l}\text { Durable drug-eluting } \\
\text { bare stent (DES-I) }\end{array}$} & Durable metal & Microporous/textured & None & Yes & \\
\hline & --stainless steel & & & Sirolimus & Yukon \\
\hline & --stainless steel & $\begin{array}{c}\text { Textured only } \\
\text { on abluminal surfaces }\end{array}$ & & Biolimus A9 & BioFreedom \\
\hline & & Laser-cut & & & NEVO \\
\hline & & $\begin{array}{c}\text { Reservoirs partially filled } \\
\text { with a drug and PLGA } \\
\text { Carbon-coated; } \\
\text { Then deep abluminal } \\
\text { reservoirs cutalong the } \\
\text { struts and filled with a } \\
\text { drug }\end{array}$ & & Siromilus & $\begin{array}{l}\text { Janus Flex } \\
\text { (tater known as } \\
\text { Optima) }\end{array}$ \\
\hline \multirow{4}{*}{$\begin{array}{l}\text { Durable early-and } \\
\text { new-generation } \\
\text { polymer-coated } \\
\text { stent (DES-II) }\end{array}$} & $\begin{array}{l}--\mathrm{Co}-\mathrm{Cr} \\
--\mathrm{Co}-\mathrm{Cr} \\
--\mathrm{Pt}-\mathrm{Cr}\end{array}$ & & $\begin{array}{l}\text { PBMA and PVDF-HFP } \\
\text { PBMA and PVDF-HFP } \\
\text { PBMA and PVDF-HFP }\end{array}$ & $\begin{array}{l}\text { Everolimus } \\
\text { Everolimus } \\
\text { Everolimus }\end{array}$ & $\begin{array}{c}\text { Xience } \\
\text { Xpedition } \\
\text { PromusElement }\end{array}$ \\
\hline & --Stainless steel & & SIBS & Paclitaxel & Taxus Liberte \\
\hline & --Stainless steel & & PEVA andPBMA & Sirolimus & Cypher \\
\hline & --Co-Cr & & $\begin{array}{l}\text { MPC, LMA, HPMA, } \\
\text { and 3-MPMA }\end{array}$ & Zotarolimus & Endeavor \\
\hline \multirow[t]{4}{*}{$\begin{array}{l}\text { Partiallybioresorbable } \\
\text { Stent (PBRS-I) }\end{array}$} & Durable metal & Plain & $\begin{array}{l}\text { Bioresorbable } \\
\text { polymer }\end{array}$ & Yes & \\
\hline & --Co-Cr & & PLLA & Novolimus & DESyne \\
\hline & --Co-Cr & & PDLC & Sirolimus & Ultimaster \\
\hline & --Pt-Cr & & PLGA & Everolimus & SYNERGY \\
\hline $\begin{array}{c}\text { Partially } \\
\text { bioresorbable } \\
\text { Stent (PBRS-II) }\end{array}$ & Durable metal & Coated & $\begin{array}{c}\text { Bioresorbable } \\
\text { polymer }\end{array}$ & Yes & \\
\hline
\end{tabular}




\begin{tabular}{|c|c|c|c|c|c|}
\hline & --Stainless steel & $\begin{array}{l}\text { Coated with apolysaccharide } \\
\text { matrix thatcontains } \\
\text { anti-human CD34antigen }\end{array}$ & PLLA + PLGA & Sirolimus & $\begin{array}{c}\text { Combo } \\
\text { Dual Therapy }\end{array}$ \\
\hline $\begin{array}{l}\text { Partially } \\
\text { bioresorbablestent } \\
\text { (PBRS-III) }\end{array}$ & $\begin{array}{l}\text { Desaminotyrosine } \\
\text { polycarbonate }+ \\
\text { iodine molecules }\end{array}$ & & & Sirolimus & ReZone \\
\hline \multirow[t]{2}{*}{$\begin{array}{l}\text { Fully bioresorbable } \\
\text { metallic stent } \\
\text { (FBRS-I) }\end{array}$} & $\begin{array}{c}\text { Bioresorbable } \\
\text { metal }\end{array}$ & Plain & None & None & \\
\hline & --Mg alloy (WE 43) & & & & AMS-1 \\
\hline $\begin{array}{l}\text { Fully bioresorbable } \\
\text { metallic/polymeric } \\
\text { stent (FBRS-II) }\end{array}$ & $\begin{array}{c}\text { Bioresorbable } \\
\text { metal }\end{array}$ & Plain & $\begin{array}{c}\text { Bioresorbable } \\
\text { polymer }\end{array}$ & Yes & \\
\hline \multirow[t]{3}{*}{$\begin{array}{l}\text { Fully bioresorbable } \\
\text { polymeric stent } \\
\text { (FBRS-III) }\end{array}$} & $\begin{array}{c}\text { Bioresorbable } \\
\text { polymer }\end{array}$ & Plain & $\begin{array}{c}\text { Bioresorbable } \\
\text { polymer }\end{array}$ & Yes & \\
\hline & --PLLA & & PDLLA & Everolimus & $\begin{array}{l}\text { Absorb BVS } \\
\text { (Absorb GT1) }\end{array}$ \\
\hline & --PLLA & & PLLA & Novolimus & DESolve 100 \\
\hline
\end{tabular}

${ }^{a}$ Driver MP35N: Medtronic Vascular, Santa Rosa, CA, USA; Omega: Boston Scientific, Boston, MA, USA; Titan: Hexacath; Genous: Orbis Neich, Hoevelaken, The Netherlands; Yukon:Translumina; BioFreedom: Biosensors; NEVO: Cordis Corp., Bridgewater, NJ, USA; JANUS FLEX: Sorin, Italy; Xience and Xpedition: Abbott Vascular, Santa Clara, CA, USA; Promus Element: Boston Scientific, Natick, MA, USA; Taxus Liberte: Boston Scientific; Cypher: Cordis/Johnson \& Johnson, Miami, FL, USA; Endeavor: Medtronic Vascular; DESyne BD: Elixir Medical; Ultimaster: Terumo Corp., Tokyo, Japan; SYNERGY: Boston Scientific, Boston, MA, USA; Combo Dual Therapy: OrbusNeich; ReZone: REVA Medical; AMS-1: Biotronik (Berlin, Germany); DREAMS 2G: Biotronik; Absorb BVS (Absorb GT1): Abbott

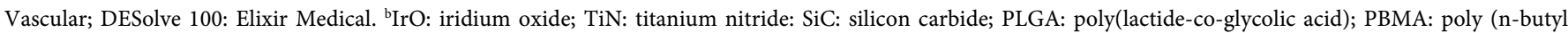
methacrylate); PVDF-HFP: co-polymer of vinylidene fluoride) and hexafluoropropylene; SIBS: poly(styrene-b-isobutylene-b-styrene); PEVA: poly(ethylene-co-vinyl acetate); MPC: methacryloyloxyethyl phosphorylchlonine; LMA: lauryl methacrylate; HPMA: hydroxypropyl methacrylate; 3-MPMA: 3-(trimethoxysilylpropyl methacrylate); PLLA: poly(l, lactic acid); PDLC: poly(d,l-lactide-co-caprolactone); PDLLA: poly(D, L-lactic acid).

artery wall cellular proliferation, may cause persistent vasomotor dysfunction, is associated with high rate of acquired late malposition, and maintains the need for prolonged dual anti-platelet therapy (DAPT) (which may cause frequent bleeding events, especially in elderly patients and in those who use oral anti-coagulant agents. A bioresorbable stent has a number of potential advantages over a durable stent [30] [41], several of which are outlined here. The former type of stent 1) may be monitored with a non-invasive technique, such as advanced multi-slice computed tomography or magnetic resonance imaging, without causing any metallic artifacts; 2) might restore late expansive remodeling, favorable vascular dynamics, adaptive shear stress, and late lumen enlargement, each of which may contribute to decreased rates of neo-atherosclerosis, in-segment restenosis (ISR), and in-stent thrombosis (ST); 3) has low possibility for strut fracture; and 4) obviates the need for prolonged DAPT, thus minimizing the risk for bleeding in high-risk patients such as elderly ones and those on oralanti-coagulants [39] [40] [41] [42] [43]. Furthermore, after resorption of a bioresorbable stent, 1) there will be full restoration of vascular architecture, endothelium function 
within the stented area of the artery segment, vasomotion, distensibility, pulsatility, and mechano-transduction; 2) a thick circumferential fibrous layer similar to a thick fibrous cap will be left behind, which may facilitate reduction of the plaque burden; and 3) there will be the option for repeat revascularization (via CABG or PTCI) in or outside the area of original stenting, an option that is particularly important in certain cases, such as those involving bifurcating lesion(s) [47] [48].

A FBRS is not without its share of shortcomings, some being embolization of partially degraded material (in all designs); low radial support duration (in some designs), and upon resorption, inorganic salts are produced, which cannot be incorporated into metabolic pathways (in some designs), and low strut profile (in some designs). In the case of bioresorbable stents in which the scaffold is fabricated from either $\mathrm{Mg}$ or a $\mathrm{Mg}$ alloy (AZ31 alloy or AZ91 alloy; for the compositions of these alloys as well as of all the other commercial alloys referred to in the present review, see Table 2) and which, currently, either are approved (for example, by the US Food and Drug Administration or have CE mark) or are undergoing clinical trials, an additional drawback is the resorption time is short ( $\sim 9$ mo- $\sim 24 \mathrm{mo}$ ) [30] [33]. This is because of the fast corrosion rate of the material (at body fluid pH ( 7.4 or even lower due to secondary acidosis from metabolic and resorptive processes that occur after surgery)) [36], the corrosion product, $\mathrm{Mg}(\mathrm{OH})_{2}$, is unstable, unprotective (it does not cover the surface of the stent) and, in fact, facilitates corrosion) [30] [33]. Furthermore, the constant exposure of high $\mathrm{Cl}^{-}$containing electrolyte causes further corrosion of the stent. Consequences of this high corrosion rate (resorption rate) of the stent include (because of micro-galvanic corrosion occurring as a result of interaction between intermetallic phases and the matrix) [30] [33]. Thus, the resorption rate of these stents is also high, with the same aforementioned consequences.

Table 2. Compositions of all the alloys referred to in the present review.

\begin{tabular}{|c|c|}
\hline Alloy designation & Composition (in wt.\%) \\
\hline AM60-2\%RE & $\mathrm{Mg}-(5.47-5.61) \mathrm{Al}-(1.73-1.94) \mathrm{Ce}-(0.27-0.32) \mathrm{Mn}(0.10-0.14) \mathrm{La}$ \\
\hline AM60B & $\mathrm{Mg}-(5.6-6.4) \mathrm{Al}-(0.26-0.40) \mathrm{Mn}-0.20 \mathrm{Zn}$ \\
\hline AZ31 & $\mathrm{Mg}-3 \mathrm{Al}-1 \mathrm{Zn}$ \\
\hline AZ61 & $\mathrm{Mg}-6.5 \mathrm{Al}-1.0 \mathrm{Zn}-0.15 \mathrm{Mn}$ \\
\hline AZ80 & $\mathrm{Mg}-(7.8-9.2) \mathrm{Al}-(0.20-0.80) \mathrm{Zn}-0.12 \mathrm{Mn}-0.10 \mathrm{Si}-0.05 \mathrm{Cu}-0.005 \mathrm{Fe}-0.005 \mathrm{Ni}$ \\
\hline AZ91 & Mg-9Al-0.9Zn-0.2Mn-0.1S-0.002Fe- $0.0005 \mathrm{Ni}$ \\
\hline GZ51K & $\mathrm{Mg}-5 \mathrm{Gd}-1 \mathrm{Zn}-0.6 \mathrm{Ar}$ \\
\hline WE43 & $\mathrm{Mg}-36.48 \mathrm{O}-10.71 \mathrm{Al}-5.06 \mathrm{Mn}-0.89 \mathrm{Y}-0.50 \mathrm{~K}$ \\
\hline ZK60 & $\mathrm{Mg}-(4.8-6.2) \mathrm{Zn}-\geq 0.45 \mathrm{Zr}$ \\
\hline $\mathrm{ZM} 21$ & $\mathrm{Mg}-2 \mathrm{Zn}-\geq 0.5 \mathrm{Mn}$ \\
\hline
\end{tabular}


Regardless of the type of stent, there are a number of common shortcomings or challenges, four of which are highlighted here. First, Initial expansion of the artery (during deployment of a stent) may result in disruption of the internal or external elastic laminae, both phenomena being associated with high risk for restenosis. Second, a stent provokes changes in the mechanical stress in the artery wall, with the extent of these changes depending on stent design and plaque properties. Third, a stent disturbs the blood flow pattern through the artery. Fourth, there is always the possibility for fracture of the stent, causing mechanical restenosis through loss of the radial strength of the stent.

\subsection{Clinical Performance}

There are some clinical problems that are specifically associated with each stent type. With BMSs, there are many reports of ISR (due to neointimal hyperplasia caused by vascular injury [31]) and a few reports of late stent thrombosis (ST) (that is, IST that occurs between $30 \mathrm{~d}$ and $1 \mathrm{y}$ after stent implantation [48]. In the case of durable polymer-coated DESs, the main clinical complications are LST and very-late in-stent thrombosis (VLST) (which is ST that occurs more than $1 \mathrm{y}$ after stent implantation [48]), with the causes being incomplete re-endothelialization of the stent strut, chronic inflammation brought about by the presence of the polymer coating after elution of the drug is complete, and artery remodeling [27] [48] [50] [51]. For PBRSs, the incidence of ST is low (for example, $0 \%-0.56 \%$ and $1.59 \%$ at 6 mo and 24 mo follow-up, respectively [28] [52].

There is a small, but growing, literature on the clinical performance of FBRSs. In a meta-analysis of the results from 3 RCTs involving comparison of the safety and efficacy of a "newer bioresorbable polymer stent" and a "new generation DES", the difference in each of the outcomes (rate of cardiac death, peri-procedural acute myocardial infarction, target-vessel revascularization (TVRV), and probable/definite stent thrombosis) was not significant [53]. In a meta-analysis of the results from 4 RCTs, it was found that the difference between Absorb BVS stent and a new-generation polymer-coated DES (Xience) with regard to either rate of composite patient-oriented adverse events (namely, myocardial infarction, revascularization, and death) or rate of stent-related adverse events was not significant [54]. In a systematic review and meta-analysis of the results from 10 RCTs in which Absorb BVS was compared to a Xience stent and a BMS (MultiLink Vision) at follow-up of 13 mo, it was found that Absorb BVS had a significantly higher risk of target vessel myocardial infarction (TVMI) and comparable rates of occurrence of other outcomes, such as cardiac death and TVRV [55]. In another systematic review and meta-analysis of the results from 6 RCTs and 38 observational studies in which Absorb BVS was compared to a new-generation polymer-coated everolimus-eluting stent (herein, designated EES) at follow-up of $13 \mathrm{mo}$, it was found that while relative rates of cardiac death, revascularization, and target lesion failure were each similar for Absorb BVS and the EES, the risk for ST and TVMI were each higher with the former stent [56]. For Absorb BVS, at follow-up of $12 \mathrm{mo}$, target lesion revas- 
cularization (TLRV) and peri- procedural myocardial infarction (PPMI) were each significantly higher for lesions treated with multiple stents compared with those treated with a single stent [57]. In a short-term (6 mo follow-up) small-scale (123 patients) RCT involving the DREAMS $2 \mathrm{G}$ (BIOSOLVE II trial), rates of target lesion failure, cardiac death, PPMI, and TLRV were $3 \%,<1 \%,<1 \%$, and $2 \%$, respectively [58].

Furthermore, the results of a network meta-analysis of 147 trials involving a FBRS, a BMS, and several variants of contemporary DESs found that, at 1 year follow-up, the FBRS had higher risk of ST than each of the others Furthermore, in a meta-analysis and systematic review of the results from 11 RCTs in which a collection of PBRSs and one FBRS (DREAMS 2G) (biolimus-, everolimus-, or sirolimus-eluting) were compared to a collection of new-generation drug-eluting polymer coated stent designs (everolimus- or zotarolimus-eluting), low incidence of complications, such as ST, TLRV, myocardial infarctions, and death were reported for the FBRS [59]. In a prospective multicenter study involving implantation of DESolve in 16 patients, there were low in-stentlate lumen loss and low percentage neointimal volume at $6 \mathrm{mo}$, and no chronic recoil and maintenance of lumen patency at $12 \mathrm{mo}$ [60].

The current consensus is that, when all the available results regarding clinical outcomes when a FBRS is used are considered, adoption of any of the current-generation FBRSs must be done with caution [61]. It is pointed out that this suggestion is based on the lack of meta-analysis of results from high-powered RCTs on this topic. Such RCTs are herein, defined as trials that have the following characteristics: conducted in at least five hospitals/centers located in at least 5 different countries; number of patients, at least 500; duration, at least three years; involving a multitude of FBRSs (for example, one design versus other designs; one design versus a counterpart new-generation DES; and one design versus a BMS) [62].

\section{Approaches to Increase Resorption Time}

\subsection{Categorization}

To reduce corrosion rate (that is, increase resorption time), the approaches that may be taken may be grouped into six categories (Figure 3).

\subsection{Alloy Modification}

In general, alloying elements whose standard electrode potential $\left(\mathrm{E}^{\circ}\right)$ is about the same as that of $\mathrm{Mg}\left(\mathrm{E}^{\circ}{ }_{\mathrm{M}}=-2.3 \mathrm{~V}\right)$ or form intermetallic phases with $\mathrm{E}^{\circ}-\mathrm{E}^{\circ}{ }_{\mathrm{M}}$ lead to an increase in the corrosion resistance of $\mathrm{Mg}$ because they reduce the likelihood for the occurrence of internal galvanic corrosion [63]. Examples of such elements are $\mathrm{Y}, \mathrm{Nd}$, and $\mathrm{Ce}\left(\mathrm{E}^{\circ}=-2.37,-2.43\right.$, and $-2.48 \mathrm{~V}$, respectively [63]. An important point to highlight is that the corrosion resistance improvement provided by any of these alloying elements (as well as by others, such as $\mathrm{Al}, \mathrm{Zn}, \mathrm{Mn}, \mathrm{Zr}, \mathrm{Sr}, \mathrm{Sn}$, and $\mathrm{Gd}$ ) only occurs when its concentration < its tolerance limit in $\mathrm{Mg}$ [63]. 


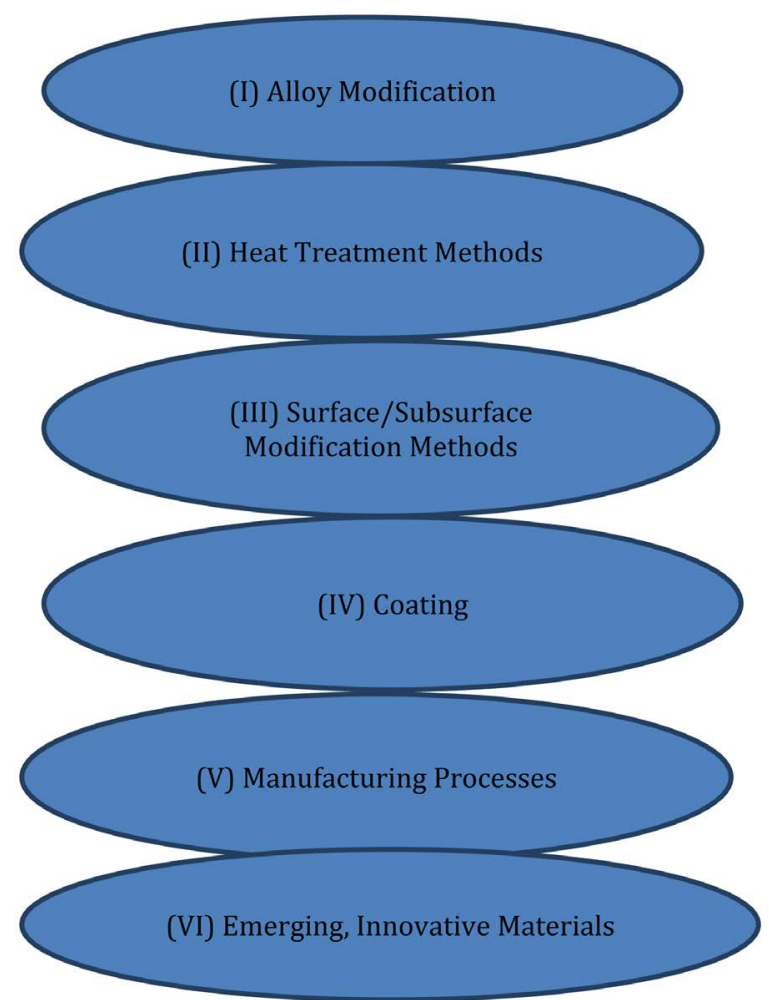

Figure 3. A schematic summary of the categorizes of approaches to reduce the degradation rate of a Mg-based fully bioresorbable Mg-based coronary artery stent.

For $\mathrm{Mg}-5 \mathrm{Ca}$ alloy specimens in Hank's solution, the rate of hydrogen evolution decreased with increase in $\mathrm{Zn}$ content of the alloy $\left(\mathrm{C}_{\mathrm{Zn}}\right)$; for example, after immersion for $60 \mathrm{~h}$, the rates were $\sim 92 \%$ and $\sim 98 \%$ lower with alloys containing $\mathrm{C}_{\mathrm{Zn}}$ of 0.5 and 5.0 wt\%, respectively, compared to the pure $\mathrm{Mg}$ [64]. These results were explained as the selective corrosion of the $\mathrm{Mg}_{2} \mathrm{Ca}$ phase, a consequence of the formation of microgalvanic couples being retarded by the $\mathrm{Zn}$ and this retardation effect increasing with increase in $C_{\mathrm{Zn}}[64]$.

\subsection{Heat Treatment Methods}

Examples of treatment methods that have been successful in increasing corrosion resistance are aging, alkaline treatment, solution treatment, and laser surface melting.

\subsubsection{Aging}

Aging creates a microstructure that contains well-dispersed precipitates. For example, most of the equiaxed-Mg grains in an as-extruded GZ51K alloy specimen have longperiod stacking ordered structure but some do not have this structure [65]. After being aged at $180^{\circ} \mathrm{C}, 200^{\circ} \mathrm{C}$ or $220^{\circ} \mathrm{C}$, the long-elongated grains that form in the as-extruded alloy specimen disappear, resulting in uniform corrosion and, hence, enhanced corrosion resistance [65]. Thus, after immersion in simulated body fluid, at $37^{\circ} \mathrm{C}$, for $120 \mathrm{~h}$, the corrosion rate of specimens aged at $200^{\circ} \mathrm{C}$ were $46 \%$ lower than that of as-extruded specimens [65]. 


\subsubsection{Alkaline Heat Treatment}

This treatment was applied to $\mathrm{Mg}$-Ca specimens, with the process comprising soaking in an alkaline $\mathrm{NaHPO}_{4}$ solution for $24 \mathrm{~h}$ followed by heating at $500^{\circ} \mathrm{C}$ for $12 \mathrm{~h}$. This treatment produced a layer with composition of $\mathrm{MgNaPO}_{4}$ on the surface of the specimen, which serves as a protective layer [66]. The corrosion rate of a treated specimen decreased by $\sim 83 \%$ compared to that of an untreated specimen [66].

\subsubsection{A Two-Step Solution Treatment}

This treatment of AM60-2\%Re specimens modified with small amounts of $\mathrm{Zn}(0.2 \mathrm{wt} \%$, or $0.5 \mathrm{wt} \%$, or $0.8 \mathrm{wt} \%$ ) involved heating at $420^{\circ} \mathrm{C}$ for $2 \mathrm{~h}$ followed by heating at $540^{\circ} \mathrm{C}$, or $560^{\circ} \mathrm{C}$, or $580^{\circ} \mathrm{C}$ for $8 \mathrm{~h}$, and, finally, quenching, in water [67]. In $3.5 \mathrm{wt} \% \mathrm{NaCl}$ solution, the corrosion rate (as determined from polarization measurements and the Tafel extrapolation method) decreased markedly with increase in $\mathrm{Zn}$ content [67]. This trend was also seen in the estimates of corrosion parameters obtained from electrochemical impedance spectroscopy (EIS) results; for example, charge transfer resistance, which is inversely proportional to corrosion rate, increased markedly with increase in $\mathrm{Zn}$ content [67]. The trend in these results was consistent with increase in $\mathrm{Zn}$ content leading to 1) increased volume fraction of Al-Re phases (these phases serve as barrier to the propagation of corrosion); and 2) decrease in the size of the leaf-like corrosion products and the amounts of oxides of four of the five alloying elements ( $\mathrm{Al}, \mathrm{Ce}, \mathrm{La}$, and $\mathrm{Zn}$ ), both phenomena of which facilitated the formation of compact, passive corrosion-resistant films [67]. There were no corrosion rate results given for specimens of the alloy with no $\mathrm{Zn}$ addition [67]; as such, the extent to which $\mathrm{Zn}$ addition impacted corrosion rate of the alloy is unknown.

\subsubsection{Laser Surface Melting}

For specimens of $\mathrm{AM} 60 \mathrm{~B}$ treated using a $10 \mathrm{~kW}$ continuous-wave $\mathrm{CO}_{2}$ laser, there was $87 \%$ drop in corrosion rate in $3.5 \mathrm{wt} \% \mathrm{NaCl}$ solution, at room temperature [68]. The reasons for this are that laser surface melting increases the solid solubility of $\mathrm{Al}$, thus enriching $\mathrm{Al}$ in the $\alpha-\mathrm{Mg}$ matrix. This increased resistance to general corrosion causes the refined intermetallic compounds to be uniformly distributed in the $\alpha-\mathrm{Mg}$ matrix, thereby reducing micro-galvanic corrosion and localized corrosion [68].

\subsection{Surface/Subsurface Modification Methods}

Two such methods are highlighted, namely, deep rolling and severe plasticity burnishing integrated with cryogenic cooling ("cryogenic burnishing" (CB)).

Deep rolling (DR) involves applying a rolling tool to finish a workpiece that had been turned. This leads to development of a large compressive residual stress deep into the subsurface of the workpiece (at a depth of $800 \mu \mathrm{m}$ ) in combination with sealing microcracks and pores in the surface, leading to increased corrosion resistance. For example, for $\mathrm{Mg}-3 \mathrm{Ca}$ alloy specimens immersed in $0.9 \mathrm{wt} \% \mathrm{NaCl}$ solution, the corrosion rate (calculated from the hydrogen evolution results) of a DR specimen (rolling force: $200 \mathrm{~N}$ or $500 \mathrm{~N}$ ) was $<1 \%$ that of a turned specimen [69]. 
The steps in cryogenic burnishing (CB) may be summarized thus: The workpiece is fixed in the chucks of a lathe and then rotated during processing. To standardize initial burnishing conditions, a machining clearance cut is made on the workpiece to reduce its diameter by about $1 \%$ (typical feed rate: $0.1 \mathrm{~mm} \cdot \mathrm{rev}^{-1}$; typical cutting speed: 100 $\mathrm{m} \cdot \mathrm{min}^{-1}$ ). Then, a fixed roller is pushed against the disc (typical feed rate: 0.01 $\mathrm{mm} \cdot \mathrm{rev}^{-1}$ ) and the burnishing speed (linear speed of the contact point between the fixed roller and the workpiece) is set to, typically, $100 \mathrm{~m} \cdot \mathrm{min}^{-1}$. During the rolling, a cryogenic cooling agent (usually, liquid nitrogen) is sprayed onto the tool-workpiece interface. This suppresses the temperature rise that, normally, would occur at that interface (because of friction). After the workpiece diameter is reduced by, typically, 2\%, the process is stopped [70]. CB produces a fine-grained microstructure at larger depths, thereby generating a fine surface finish. In $5 \mathrm{wt} \% \mathrm{NaCl}$ solution, hydrogen evolution amount (corrosion rate) of specimens of CB AZ31 is about half that of a specimen that is ground using a traditional process (Figure 4), reflecting 1) the effect of the substantial amount of grain size refinement that $\mathrm{CB}$ produced (mean longitudinal axis grain size of as-received specimens $=11.9 \pm 4.5 \mu \mathrm{m}$ and mean grain size near the topmost layer in a $\mathrm{CB}$ specimen $=523 \pm 131 \mathrm{~nm}$ ); and 2) the relative size of the pits created by $\mathrm{CB}$ and grinding: small and large, respectively [70].

\subsection{Coating}

A large collection of methods have been used to coat $\mathrm{Mg}$ and $\mathrm{Mg}$ alloy parts with one or more layers of an inorganic or organic material. Among the methods are chemical conversion treatment, implantation of ions of a gas, metal, or mixture of gas and metal, micro-arc oxidation (also called plasma electrolytic anodization or anodic spark deposition), electrophoretic deposition, sol gel deposition, physical vapor deposition, and radiofrequency magnetron sputtering. Examples of single-layer coatings are $\mathrm{MgF}_{2}$, nanohydroxyapatite, akernanite, and silver doped tricalcium phosphate and examples of multi-layer coatings are $\mathrm{Ni}-\mathrm{P}-\mathrm{ZrO}_{2}$, TiO-poly (lactic acid), and $\mathrm{MgF}_{2}-\mathrm{HA}$ [35]

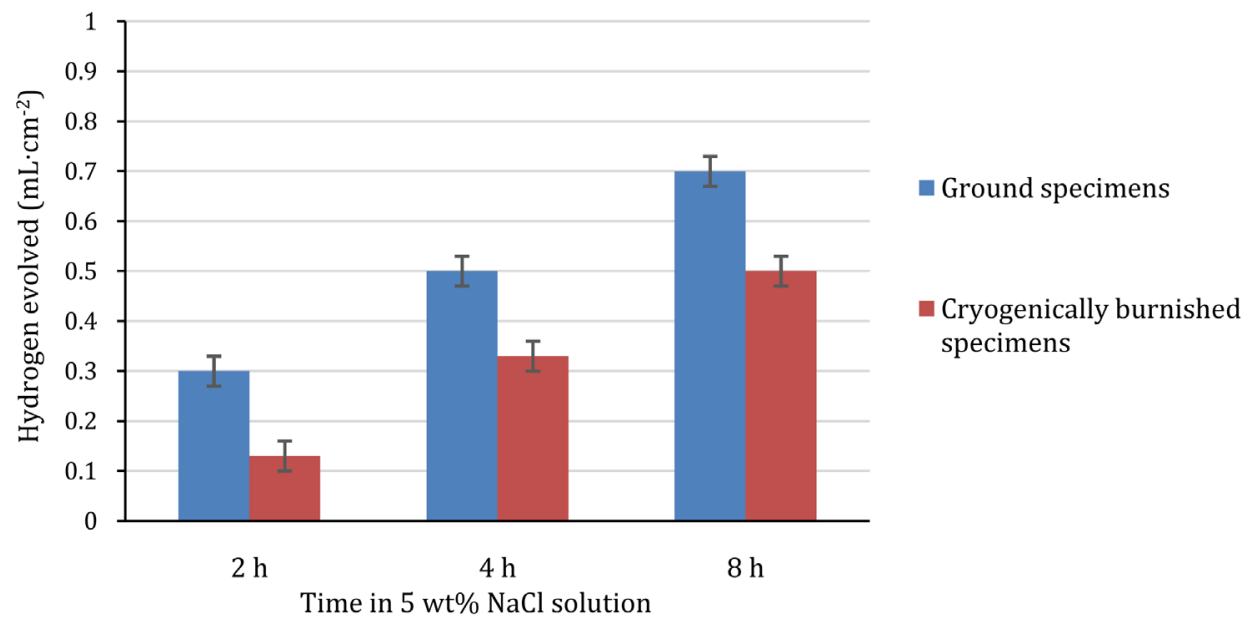

Figure 4. Comparison of hydrogen evolution obtained using ground and cryogenically burnished and ground specimens (Constructed from results given by $\mathrm{Pu}$ et al. [70]). 
[44] [71] [72]. It is worth noting that not all coatings have a desirable effect on the corrosion resistance of the substrate, a case in point being Ti ions implanted in AZ91 specimens produced only a very modest improvement [73]. A summary of various features of a sample of deposited coatings and methods of deposition that lead to various amounts of decrease in corrosion rate of $\mathrm{Mg}$ and $\mathrm{Mg}$ alloy specimens (relative to the rate in uncoated counterpart specimens) is given in Table 3 . In each case, the improvement is attributed to the coating serving as an effective barrier to the ingress of the electrolyte to the substrate.

Table 3. Summary of features of a sample of coatings on $\mathrm{Mg}$ and $\mathrm{Mg}$ alloy specimens ${ }^{\mathrm{a}}$.

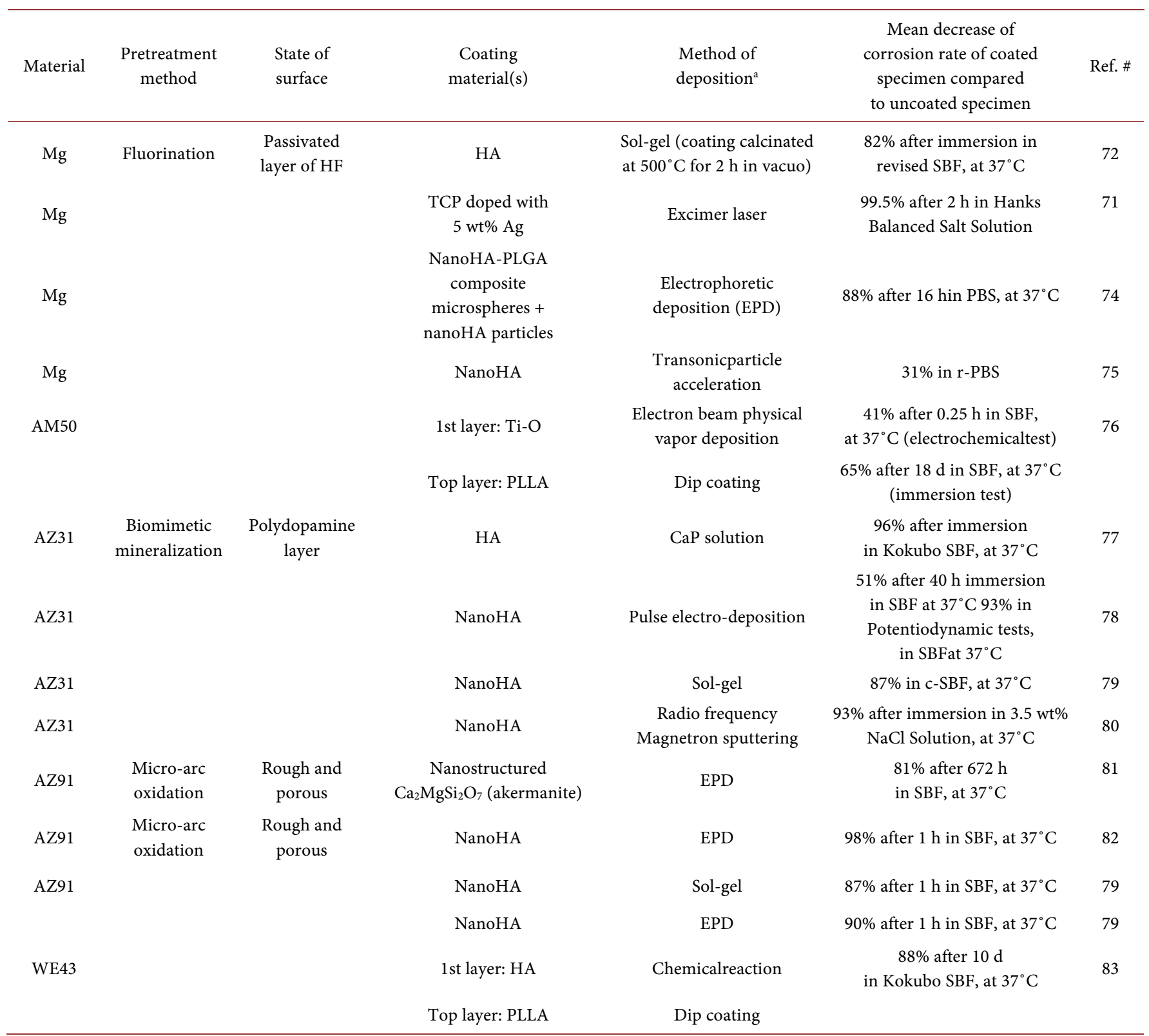

${ }^{a}$ HF: hydrogen fluoride; HA: hydroxyapatite; SBF: simulated body fluid; TCP: tricalcium phosphate; PLGA: poly(lactic-co-glycolic acid\}; PBS: phosphate buffered saline solution; r-PBS: revised phosphate buffered saline solution; PLLA: poly(l, lactic acid); CaP: calcium phosphate; c-SBF: corrected simulated body fluid. 


\subsection{Manufacturing Processes}

Manufacturing processes, such as extrusion and rolling, that lead to grain size refinement of the metallic material lead to marked reduction of the corrosion rate of the material. For example, after $75 \mathrm{~d}$ in Hank's solution $(\mathrm{pH}=7.4)$, the hydrogen evolution amount of 1) extruded $\mathrm{Mg}$ (mean grain size $\left(\mathrm{d}_{\mathrm{M}}\right)=25 \mu \mathrm{m}$ ) was $\sim 98 \%$ lower than that of as-cast $\mathrm{Mg}\left(\mathrm{d}_{\mathrm{M}}=1 \mathrm{~mm}\right)$ [64]; and 2) extruded Mg-5Ca-1Zn $\left(\mathrm{d}_{\mathrm{M}}=10 \mu \mathrm{m}\right)$ was $\sim 15 \%$ lower than that of its as-cast counterpart $\left(\mathrm{d}_{\mathrm{M}}=1 \mathrm{~mm}\right)$ [63]. After $20 \mathrm{~d}$, in Hank's solution, hot-rolled AZ31 specimens displayed $\sim 98 \%$ lower corrosion rate than their squeeze-cast counterparts, as a result of lower $\mathrm{d}_{M}$ of the former [84]. One phenomenon that has been postulated to lead to grain size refinement is particle-pinning effect (sometimes, called the redistribution effect) of the second phase in the metal [63] [64]. In fact, it has been suggested that there is a Hall-Petch-type relationship between corrosion rate and $d_{M}$ [85]. However, some results are inconsistent with this suggestion; for example, 1) for six alloys (WE43, AZ80, AZ61, AZ31, ZK60, and ZM21), the order of their corrosion rates in a static medium is different from the order of their corrosion rates in a hydrodynamic medium [86]; and 2) for an AZ31 components manufactured using equal channel angular pressing [85], which has a lower $\mathrm{d}_{\mathrm{M}}(\sim 2.5 \mu \mathrm{m})$ than its rolled counterpart, has a higher corrosion rate [63]. Two other phenomena that have been suggested for the decreased corrosion rate of an extruded specimen are high grain boundary density and high dislocation density [63].

\subsection{Emerging, Innovative Materials}

An example of such materials is a composite fabricated using powders of $\mathrm{Mg}$, nanoHA (mean particle size $<100 \mathrm{~nm}$ ), and nanoMgO powder (mean particle size $<100 \mathrm{~nm}$ ) as the raw materials, yielding the following four compositions: $72.5 \mathrm{Mg}-27.5 \mathrm{nHA}(\mathrm{MH})$, $75 \mathrm{Mg}-20 \mathrm{nHA}-5 \mathrm{MgO}$ (MHM5), and $77.5 \mathrm{Mg}-12.5 \mathrm{nHA}-10.0 \mathrm{MgO}$ (MHM10), and 80Mg-5nHA-15MgO (MHM15) [87]. The specimens were produced using a blend-cold press-sinter powder metallurgy method; specifically 1 ) the powder blend was dried in a vacuum oven $\left(220^{\circ} \mathrm{C}\right.$ for $\left.\left.10 \mathrm{~h}\right) ; 2\right)$ the dried blend was mixed using a planetary ball mill ( $2 \mathrm{~h}$; Ar atmosphere); and 3) the mixture was pressed (840 MPa) and then sintered $\left(400^{\circ} \mathrm{C}\right.$; $1.5 \mathrm{~h}$; Ar atmosphere) [87]. In Kokubo SBF, at $27^{\circ} \mathrm{C}$, the corrosion rate of specimens of these composites was $4.28,4.65,1.06$, and $1.94 \mathrm{~mm} /$ year [87]. In the case of the MHM10 specimens, the corrosion products were, mainly, $\mathrm{Mg}(\mathrm{OH})_{2}$ nanorods, which have a hierarchical structure; $\mathrm{HA}$; and $\mathrm{Ca}\left(\mathrm{PO}_{4}\right)_{2}$ [87]. Growth of $\mathrm{Mg}(\mathrm{OH})_{2}$ nanorods in the specimen increased the contact angle between the solution and the substrate, resulting in the substantially decreased hydrogen evolution rate [87]. Another contribution to this excellent corrosion performance is decrease in the number of pores and voids around the HA agglomerates, which reduced penetration of the electrolyte into the matrix. It is to be noted that the corrosion rate of the MHM10 specimens (1.06 $\mathrm{mm} \cdot \mathrm{yr}^{-1}$ ) was $\sim 50 \%$ lower than the consensus threshold $\left(2 \mathrm{~mm} \cdot \mathrm{yr}^{-1}\right)$ [87].

\subsection{Appraisal of Approaches}

A straightforward comparison of the effectiveness of the different approaches is com- 
plicated by several factors. First, in some reports, results for the baseline material were not given, an example being the report on the two-step solution treatment method [67]. Second, in other reports, data on important material characteristics that influence corrosion were not given, an example being the report on the relationship between the grain size of the material and its corrosion rate [64]. Third, in some reports, counterpart materials was not given, an example being the report on nanocomposites in which each of the materials had a different composition [87]. Fourth, there were differences in terms of 1) the aqueous biosimulating solutions were used; for example, Hank's solution [64], $5 \mathrm{wt} \% \mathrm{NaCl}$ [70]; physiological saline solution [71]; simulated body fluid [76] [81], Kokubo simulated body fluid [87]; and 2) the test techniques; for example, mass loss measurement [63] [65] [67] [69] [81] [84] [87], hydrogen gas evolution measurement [64] [69] [70], potentiodynamic polarization measurements [65] [67] [71] [72] [76] [81] [87], and electrochemical impedance spectroscopy (EIS) [67] [71] [72] [81].

While cognizant of the issues discussed above, it seems that it would still be useful to identify the methods that, by and large, produced the largest decreases in corrosion rate (the threshold being taken to be $\geq 80 \%$ ). These are the alkaline heat treatment, laser surface melting, coating with nanHA, and deep rolling. Thus, these methods may be considered when developing the next generation of plain fully-bioresorbable $\mathrm{Mg}$ and Mg stents.

\section{Directions for Future Research Areas}

Directions for five potential research areas are presented. In each of these areas, the corrosion rate (determined using, for example, immersion, potentiodynamic, and/or EIS tests) should be compared to that when Mg or a specified Mg alloy (such as WE43) is the stent material. The first potential research area is optimization of each of the four methods identified in the preceding section as producing high reduction in corrosion rate. This means, for each of these methods, determine the mix of variables that yields the largest drop in corrosion rate for a given material ( $\mathrm{Mg}$ or a $\mathrm{Mg}$ alloy).

Low plasticity burnishing (LBP) is an example of a machining process that is expected to reduce the corrosion rate of $\mathrm{Mg}$ and $\mathrm{Mg}$ alloy specimens. The principle of LPB may be summarized thus. A smooth free-rolling ball $\left(\mathrm{Si}_{3} \mathrm{~N}_{4}\right.$; diameter $(\mathrm{D})=12.7$ $\mathrm{mm}$ ) supported on a spherical socket (pressurized hydro-cushion) is pressed against the surface of the workpiece. This unit is hooked onto a milling machine [88]. During the operation, the socket deforms the workpiece in the near-surface region [88]. This results in the development of compressive residual stress in that region; for example, with the pressure applied to the hydro-cushion $(\mathrm{P})$ of $6 \mathrm{MPa}$, the radial, axial, and circumferential components of that stress were determined, using acoustic emission, to be, approximately, $83 \mathrm{MPa}$ at a depth below the surface of the specimen of $800 \mu \mathrm{m}, 33 \mathrm{MPa}$ at $1000 \mu \mathrm{m}$ and $83 \mathrm{MPa}$ at $800 \mu \mathrm{m}$, respectively [88]. While it is expected that this near-surface compressive residual stress profile will result in decrease in the corrosion rate of the material, the second potential research area should be performance of experimental tests to investigate this. Furthermore, the influence of various process variables, 
notably, D, P, and number of passes, on the corrosion behavior should be investigated.

Third, emerging methods for depositing nanoHA coating on biomedical alloys should be explored on Mg-based materials currently used for fabricating FBRSs (that is, $\mathrm{Mg}$ and WE43) or may be used for such a purpose (for example, Mg-2Al-1rare earth (Ce, Nd, Pt) [36], Mg-Nd-Zn-Sr-Zr alloy [89], Mg-0.63Ca and Mg-0.89Ca alloys [90]). Examples of these methods, which, herein, are defined as those that have been used to deposit nanoHA coating on $\mathrm{Ti}$ and its alloys that lead to marked reduction in corrosion rate, are aerosol deposition (ASD) [91] [92], electrohydrodynamic spray deposition (EHDSD) [93], and liquid precursor plasma spraying (LPPS) [94]. For each method chosen, the influence of process variables on corrosion rate of the specimens should be established. For example, for ASD, key process variables are oxygen gas flow rate and evacuation pressure of the deposition chamber [91] [92]; for EHDSD, they are flow rate of nanoHA suspension and magnitude of voltage applied to the needle [93]; and for LPPS, they are composition of the primary and secondary plasma gases, power input to the plasma, and stand-off distance (distance between the specimen and the plasma jet [94]. Once the collection of optimum preparation conditions are determined, further work in this potential research area should be on determining the influence of time of immersion of the specimen in the electrolyte on two aspects. These are 1) the stability of the coating (for example, use angle-resolved X-ray photoelectron spectroscopy to determine change in composition of the coating, thickness of the coating, and composition of the coating-substrate interface); and 2) a model for the coating-substrate-electrolyte system. This could be done using results of EIS and equivalent electrical circuits (EECs). Although the EIS-EEC approach has been used in a number of corrosion studies involving $\mathrm{Mg}$ and $\mathrm{Mg}$ alloy specimens in a variety of electrolytes [67] [72] [90], there is a shortcoming in this body work that should be corrected in the work to be conducted in this third potential research area. This is that there has not been any discussion of the principal limitation of the EIS-EEC approach, which is that the circuit presented is not unique [95].

The fourth potential research area should comprise detailed studies of the corrosion properties of innovative Mg-based materials. Examples are 1) a Mg matrix composite comprising a dense uniform dispersion of 14 vol.\% of $\mathrm{SiC}$ nanoparticles in $\mathrm{Mg}-2 \mathrm{Zn}$ alloy matrix, with the dispersion achieved via a nanoparticle self-stabilization mechanism in molten metal [96]; and 2) a Mg-(1-5)Gd-(1-5)Nd-Zn-Zr alloy, which has been shown to have very low cell cytotoxicity [97].

There is a large number of additive manufacturing (AM) methods [98] [99] [100], which may be categorized in many different ways, one such being the ASTM International scheme [101], which comprises seven categories, one of them being powder bed fusion (PBF) methods. Widely used PBF methods include direct metal laser sintering (DMLS), selective laser melting (SLM), selective laser sintering (SLS), and electron beam melting (EBM). PBF methods have many attractive features, such as high accuracy, fully dense parts, and production of parts that have high specific strength and high specific stiffness [99] [100] [102]. As such, there are many reports in the literature on 
their use to fabricate a variety of metallic biomedical devices, such as patient-matched templates for thoracic pedicle screw placement [103], a mandibular prosthesis [104], and a tracheal stent [105]. However, to date, there is only a handful of reports of use of an AM method to fabricate patient-matched bioabsorbable stents and they are only prototypes [106]. The fifth potential research area should be to determine, for a given PBF method, the collection of process and post-production variables that will result in the optimal corrosion rate of a $\mathrm{Mg}$ or $\mathrm{Mg}$ alloy FBRS in human blood, at $37^{\circ} \mathrm{C}$. For DMLS, some process variables are characteristics of the particle size of the powder (for example, mode diameter and distribution), orientation of the laser machine relative to the building platform (XY plane), laser power (P), scan speed (v), and energy density (equal to $\mathrm{P} /(\mathrm{v} \times$ hatch distance $\times$ layer thickness $))$. For SLM, two key process variables are laser power level and laser scanning speed. For SLS, important process variables are laser power level, laser scan counts, and powder bed temperature. For EBM, key processing parameters are electron beam power level, electron beam scanning speed, and spacing. In essence, the task will be to determine, for a given PBF method, the values of each of the process variables that will lead to the optimum size of the melt pool. This suggestion is based on 1) the fact that the size of the melt pool exerts a significant influence on the shape, volume, and distribution of pores in a component produced any of these melt processes [99] [107]; and 2) the expectation that corrosion rate of a FBRS will be influenced by porosities in it. A relevant post-production method issurface treatment using, for example, shot peening or polishing. For shot peening, pressure, time, and diameter of glass microspheres used are important and for polishing conditions, medium and time are important.

\section{Summary}

The following is a summary of the key points made in the present review:

- Coronary artery disease (CAD) is characterized by partial or full blockage of section(s) of the artery by plaque. In nearly every country, CAD is one of the leading causes of death. When surgical interventional is deemed necessary to re-vascularize the plaque-laden artery, many options are available, with the most widely used being balloon angioplasty followed by implantation of a stent.

- On the basis of the materials used, stents have evolved from durable bare metal (principal shortcoming being high incidence of in-segment restenosis (ISR)) through durable drug-eluting (principal shortcoming being late/very late stent thrombosis (L/VLST)) to fully bioresorbable types. The last-mentioned has many theoretical advantages, such as bioresorbability, high potential for full restoration of endothelial function within the stented zone, low potential for ISR, and low potential for L/VLST, but the main shortcoming of the current generation is short resorption time, a consequence of high corrosion of $\mathrm{Mg}$ and $\mathrm{Mg}$ alloy specimens in vivo. There is a sizeable body of literature on approaches to reduce the corrosion rate of $\mathrm{Mg}$ and $\mathrm{Mg}$ alloy specimens in aqueous biosimulating media that may have implications for $\mathrm{Mg} / \mathrm{Mg}$ alloy FBRSs. 
- A review of the aforementioned body of literature categories identified these approaches as alloy modification, heat treatment methods, surface/subsurface modification methods, coatings, manufacturing processes, and use of emerging, innovative materials. The present work contains a critical summary of the results from studies on all of these approaches, leading to the overall finding that four approaches (namely, alkaline heat treatment, laser surface melting, excimer laser deposition of a $5 \mathrm{wt} \%$ Ag-doped tricalcium phosphate coating, and deep rolling) offer the greatest potential for marked reduction in corrosion rate. The review ends with suggested directions for future work, among which are 1) optimization of each of the abovementioned four processes, for a given material; and 2) fabrication using a powder bed fusion metal additive manufacturing method. Thus, information given in this review may contribute to research and development work on the next generation of plain fully-bioresorbable $\mathrm{Mg}$ and $\mathrm{Mg}$-alloy stents.

\section{References}

[1] Lusis, A.J. (2000) Atherosclerosis. Nature, 407, 233-241. http://dx.doi.org/10.1038/35025203

[2] Agema, W.R.P., Jukema, J.W., Pimstone, S.N. and Kastiein, J.J.P. (2001) Genetic Aspects of Restenosis after Percutaneous Coronary Intervention: Towards More Tailored Therapy. European Heart Journal, 22, 2058-2074. http://dx.doi.org/10.1053/euhj.2000.2589

[3] Llyod-Jones, D., Adams, R.J., Brown, T.M., Carmethon, M., et al. (2010) Heart Disease and Stroke Statistics-2010 Update: A Report from the American Heart Association. Circulation, 121, e46-e215. http://dx.doi.org/10.1161/CIRCULATIONAHA.109.192667

[4] Gouvinhas, C., Severo, M., Azevedo, A. and Lunet, N. (2014) Worldwide Patterns of Ischemic Heart Disease Morality from 1980 to 2010. International Journal of Cardiology, 170, 309314. http://dx.doi.org/10.1016/j.ijcard.2013.11.004

[5] Coronary Artery Disease Rate by Country (2014) World Health Rankings. World Health Organization, Geneva, Switzerland. http://www.worldlifeexpectancy.com

[6] Singh, G.K., Azuline, R.G., Siahpush, M. and Williams, S.D. (2015) Widening Geographical Disparities in Cardiovascular Disease Mortality in the United States, 1969-2011. International Journal of MCH and AIDS, 3, 134-149.

[7] Sidney, S., Quesenberry Jr., C.P., Jaffe, M.G., Sorel, M., Nguyen-Huynh, M.N., Kushi, L.H., Go, A.S. and Rana, J.S. (2016) Recent Trends in Cardiovascular Mortality in the United States and Public Health Goals. JAMA Cardiology, 1, 594-599. http://dx.doi.org/10.1001/jamacardio.2016.1326

[8] American Heart Association (2013) Heart and Stroke Statistics Update. American Heart Association, Dallas, TX.

[9] Brown, D.L. (2014) Review: CAGB or Stents Compared with Medical Therapy in Stable Coronary Artery Disease. Annals of Internal Medicine, 161, JC10. http://dx.doi.org/10.7326/0003-4819-161-8-201410210-02010

[10] Farooq, V. and Serruys, P.W. (2015) Bypass Grafting versus Percutaneous InterventionWhich Is Better in Multilevel Coronary Artery Disease: Lessons from SYNTAX and Beyond. Progress in Cardiovascular Diseases, 58, 316-334. http://dx.doi.org/10.1016/j.pcad.2015.10.002 
[11] Giustino, G. and Danggas, G.D. (2015) Surgical Revascularization versus Percutaneous Coronary Intervention and Optimal Medical Therapy in Diabetic Patients with Multi-Level Coronary Artery Disease. Progress in Cardiovascular Diseases, 58, 306-315.

http://dx.doi.org/10.1016/j.pcad.2015.08.005

[12] Weintraub, W.S., Grau-Sepulvedia, M.V., Weiss, J.M., O’Brien, S.M., Peterson, E.D., et al. (2012) Comparative Effectiveness of Revascularization Strategies. The New England Journal of Medicine, 366, 1476. http://dx.doi.org/10.1056/NEJMoa1110717

[13] Kaul, S., Shah, P.K. and Diamond, G.A. (2007) As Time Goes by: Current Status and Future Directions in the Controversy over Stenting. Journal of the American College of Cardiolo$g y$, 50, 128-137. http://dx.doi.org/10.1016/j.jacc.2007.04.030

[14] Stergiopoulos, K. and Brown, D.L. (2012) Initial Coronary Stent Implantation with Medical Therapy vs Medical Therapy Alone for Stable Coronary Artery Disease. Annals of Internal Medicine, 172, 312-319. http://dx.doi.org/10.1001/archinternmed.2011.1484

[15] Buchanan, G.L., Giustino, G. and Chieffo, A. (2014) Decision Making between Percutaneous Coronary Intervention or Bypass Surgery in Multi-Vessel Coronary Disease. Revista Española de Cardiología, 67, 428-431. http://dx.doi.org/10.1016/j.recesp.2013.08.017

[16] Akkus, N.I., Abdulbarki, A., Jimenez, E. and Tandon, N. (2015) Atherectomy Devices: Technology Update. Medical Devices. Evidence and Research, 8, 1-10.

[17] Akutsu, N., Takayama, T., Mineki, T., Kougo, T., Murala, N., Iida, K., Nishida, T., Oshima, T., Haruta, H., Fukamachi, D., Hiro, T. and Hirayama, A. (2016) The Effect of Drug-Coated Balloon Angioplasty for In-Stent Restenosis Evaluated by Serial Angioscopy and Optical Coherence Tomography Study. Journal of the American College of Cardiology, 67, 234. http://dx.doi.org/10.1016/S0735-1097(16)30235-2

[18] Ho, H.H., Ong, P.J.L. and Jafary, F.H. (2016) "First-in-Man" Report of Successful Use of Drug-Coated Balloon Angioplasty in Primary Percutaneous Coronary Intervention to Treat a Patient with 2 Discrete ST-Elevation Myocardial Infarction. International Journal of Cardiology, 214, 19-20. http://dx.doi.org/10.1016/j.ijcard.2016.03.097

[19] Kufner, S., Cassese, S., Voleskini, C.M., Neumann, F.-J., Schulz-Schüpke, S., et al. (2015) Long-Term Efficacy and Safety of Paclitaxel-Eluting Balloon for the Treatment of DrugEluting Stent Restenosis: 3-Year Results of a Randomized Controlled Trial. JACC: Cardiovascular Interventions, 8, 877-884. http://dx.doi.org/10.1016/j.jcin.2015.01.031

[20] Kijima, M. (2016) The Role of Revived Directional Coronary Atherectomy (DCA). Journal of the Japanese Coronary Association, 3, Article ID: 22.15-00007. http://dx.doi.org/10.7793/jcoron.22.15-00007

[21] Liou, K., Jepson, N., Cao, C., Luo, R., Pala, S. and Ooi, S.-Y. (2016) Drug-Eluting Balloon versus Second Generation Drug Eluting Stents in the Treatment of In-Stent Restenosis: A Systematic Review and Meta-Analysis. Heart, Lung and Circulation, in press. http://dx.doi.org/10.1016/j.hlc.2016.04.001

[22] Panoulas, V.F., Colombo, A., Margonato, A. and Maisano, F. (2015) Hybrid Coronary Revascularization: Promising, but Yet to Take off. Journal of the American College of Cardiology, 65, 85-97. http://dx.doi.org/10.1016/j.jacc.2014.04.093

[23] Diegeler, A. (2016) Hybrid Coronary Revascularization: The Best of 2 Worlds? Journal of the American College of Cardiology, 68, 366-367. http://dx.doi.org/10.1016/j.jacc.2016.05.029

[24] Holmes, D.R. and Taggart, D.R. (2016) Revascularization in Stable Coronary Artery Disease: A Controlled Perspective from an Interventional Cardiologist and a Cardiac Surgeon. European Heart Journal, 37, 1873-1882. http://dx.doi.org/10.1093/eurheartj/ehw044 
[25] Colombo, A., Stankovic, G. and Moses, J.W. (2002) Selection of Coronary Stents. Journal of the American College of Cardiology, 40, 1021-1033.

http://dx.doi.org/10.1016/S0735-1097(02)02123-X

[26] Popma, J.J. and Tulli, M. (2006) Drug-Eluting Stents. Cardiology Clinics, 24, 217-231. http://dx.doi.org/10.1016/j.ccl.2006.04.001

[27] Stefanini, G.G. and Holmes, D.R. (2013) Drug-Eluting Coronary-Artery Stents. The New England Journal of Medicine, 368, 254-265. http://dx.doi.org/10.1056/NEJMra1210816

[28] Jimenez, V.A., Iniguez, A., Baz, J.A., Valdes, M., Ortiz, A., et al. (2016) A Randomized Comparison of Novel Bioresorbable Polymer Sirolimus-Eluting Stent and Durable Polymer Everolimus-Eluting Stent in Patients with Acute Coronary Syndromes: The CENTURY II High Risk ACS Substudy. Cardiovascular Revascularization Medicine, 17, 355-361. http://dx.doi.org/10.1016/j.carrev.2016.04.001

[29] Katz, G., Harchandani, B. and Shah, B. (2015) Drug-Eluting Stents: The Past, Present, and Future. Current Atherosclerosis Reports, 17, 11. http://dx.doi.org/10.1007/s11883-014-0485-2

[30] Tenekecioglu, E., Farooq, V., Bourantas, C.V., Silva, R.C., Onuma, Y., Yimaz, M. and Serruys, P.W. (2016) Bioresorbable Scaffolds: A New Paradigm in Percutaneous Coronary Intervention. BMC Cardiovascular Disorders, 16, 38. http://dx.doi.org/10.1186/s12872-016-0207-5

[31] Looser, P.M., Lim, L.K. and Feldman, D.N. (2016) In-Stent Restenosis: Pathophysiology and Treatment. Current Treatment Options in Cardiovascular Medicine, 18, 10. http://dx.doi.org/10.1007/s11936-015-0433-7

[32] Ho, M.-Y., Chen, C.-C., Wang, C.-Y., Chang, S.-H., Hsieh, M.-J., Lee, C.-H., Wu, V.C.-C. and Hsien, I.-C. (2016) The Development of Coronary Artery Stents: From Bare-Metal to Bio-Resorbable Types. Metals, 6, 168. http://dx.doi.org/10.3390/met6070168

[33] Boland, E.L., Shine, B., Kelly, N., Sweeny, C.A. and McHugh, P.E. (2016) A Review of Material Degradation Modeling for the Analysis and Design of Bioabsorable Stents. Annals of Biomedical Engineering, 44, 341-356. http://dx.doi.org/10.1007/s10439-015-1413-5

[34] Ma, J., Thompson, M., Zhao, N. and Zhu, D. (2014) Similarities and Differences in Coatings for Magnesium-Based Stents and Orthopaedic Implants. Journal of Orthopaedic Translation, 2, 118-130. http://dx.doi.org/10.1016/j.jot.2014.03.004

[35] Uddin, M.S., Hall, C. and Murphy, P. (2015) Surface Treatments for Controlling Corrosion Rate of Biodegradable Mg and Mag-Based Alloy Implants. Science and Technology of Advanced Materials, 16, Article ID: 053501. http://dx.doi.org/10.1088/1468-6996/16/5/053501

[36] Hornberger, H., Virtanen, S. and Boccaccini, A.R. (2012) Biomedical Coatings on Magnesium Alloys-A Review. Acta Biomaterialia, 8, 2442-2455.

http://dx.doi.org/10.1016/j.actbio.2012.04.012

[37] Castiglioni, S. and Maier, J.A.M. (2015) Magnesium Alloys for Vascular Stents: The Biological Bases. BioNanoMaterials, 16, 23-29. http://dx.doi.org/10.1515/bnm-2015-0003

[38] O’Brien, B., Zafar, H., Ibrahim, A., Zafar, J. and Sharif, F. (2016) Coronary Stent Materials and Coatings: A Technology and Performance Update. Annals of Biomedical Engineering, 44, 523-535. http://dx.doi.org/10.1007/s10439-015-1380-x

[39] Bowen, P.K., Shearier, E.R., Zhao, S., Guillory II, R.J., Zhao, F., Goldman, J. and Drelich, J.W. (2016) Biodegradable Metals for Cardiovascular Stents: From Clinical Concerns to Recent Zn-Alloys. Advanced Healthcare Materials, 5, 1121-1140. http://dx.doi.org/10.1002/adhm.201501019 
[40] Suwannasom, P., Sotomi, Y., Tateishi, H., Tenekecioglu, E., Zeng, Y., Krank, R.P., Wykrzykowska, J.J., De Winter, R.J., Serrys, P.W. and Onuma, Y. (2016) Bioresorbable Drug-Eluting Scaffolds for Treatment of Vascular Disease. Expert Opinions on Drug Delivery, 13, 725-739. http://dx.doi.org/10.1517/17425247.2016.1153062

[41] Wayangankar, S.A. and Ellis, S.G. (2015) Bioresorbable Stents: Is This Where We Are Headed? Progress in Cardiovascular Diseases, 58, 342-55.

http://dx.doi.org/10.1016/j.pcad.2015.08.011

[42] Kang, S.-H., Chae, I.-H., Park, J.-J., Lee, H.S., Kang, D.-Y., Hwang, S.-S., Youn, T.-J. and Kim, H.-S. (2016) Stent Thrombosis with Drug-Eluting Stents and Bioresorbable Scaffolds: Evidence from a Network Meta-Analysis of 147 Trials. JACC: Cardiovascular Interventions, 9, 1203-1212. http://dx.doi.org/10.1016/j.jcin.2016.03.038

[43] Wang, Y. and Zhang, X. (2014) Vascular Restoration Therapy and Bioresorbable Vascualr Scaffold. Regenerative Biomaterials, 1, 49-55. http://dx.doi.org/10.1093/rb/rbu005

[44] Gogas, B.D., McDaniel, M., Samady, H. and King III, S.B. (2014) Novel Drug-Eluting Stents for Coronary Revascularization. Trends in Cardiovascular Medicine, 24, 305-313. http://dx.doi.org/10.1016/j.tcm.2014.07.004

[45] Testa, L., Latib, A., Montone, R.A., Colombo, A. and Bedogni, F. (2016) Coronary Bioresorbable Vascular Scaffold Use in the Treatment of Coronary Artery Disease. Circulation: Cardiovascular Interventions, 9, e003978. http://dx.doi.org/10.1161/CIRCINTERVENTIONS.116.003978

[46] Mennuni, M.G., Pagnotta, P.A. and Stefanini, G.G. (2016) Coronary Stents: The Impact of Technological Advances on Clinical Outcomes. Annals of Biomedical Engineering, 44, 488496. http://dx.doi.org/10.1007/s10439-015-1399-Z

[47] Onuma, Y., Ormiston, J. and Serruys, P.W. (2011) Bioresorbable Scaffold Technologies. Circulation Journal, 75, 509-520. http://dx.doi.org/10.1253/circj.CJ-10-1135

[48] Serruys, P.W. and Daemen, J. (2007) Are Drug-Eluting Stents Associated with a Higher Rate of Late Thrombosis than Bare Metal Stents? Circulation, 115, 1433-1439. http://dx.doi.org/10.1161/CIRCULATIONAHA.106.666826

[49] Taniwaki, M., Radu, M.D., Zaugg, S., Amabile, N. and Garcia-Garcia, H.M. (2016) Mechanisms of Very Late Drug-Eluting Stent Thrombosis Assessed by Optical Coherence Tomography. Circulation, 133, 650-660. http://dx.doi.org/10.1161/CIRCULATIONAHA.115.019071

[50] Christiansen, E.H., Jensen, L.O., Thayssen, P., Tilsted, H.-H., Krusell, L.R., et al. (2013) Biolimus-Eluting Biodegradable Polymer-Coated Stent versus Durable Polymer-Coated Sirolimus-Eluting Stent in Unselected Patients Receiving Percutaneous Coronary Intervention (SORT OUT V): A Randomized Non-Inferiority Trial. The Lancet, 381, 661-669. http://dx.doi.org/10.1016/S0140-6736(12)61962-X

[51] Smits, P.C., Hofma, S., Togni, M., Vazquez, N., Valdes, M., et al. (2013) Abluminal Biodegradable Polymer Biolimus-Eluting Stent versus Durable Polymer Everolimus-Eluting Stent (COMPARE II): A Randomised, Controlled, Non-Inferior Trial. The Lancet, 381, 651-660. http://dx.doi.org/10.1016/S0140-6736(12)61852-2

[52] Longo, G., La Manna, A., Capodanno, D. and Tamburino, C. (2015) The Ultimaster ${ }^{\circledast}$ Coronary Stent System: State of the Art. Minerva Cardioangiologica, 63, 193-203.

[53] Garcia, D., Ansari, M., Cardoso, R., Alfonso, C., Hassid, B. and Singh, V. (2016) Safety and Efficacy of Bioresorbable Polymer for Coronary Artery Disease: A Meta-Analysis of Randomized Clinical Trial. Journal of the American College of Cardiology, 67, 435. http://dx.doi.org/10.1016/S0735-1097(16)30436-3 
[54] Stone, G.W., Kimura, T., Kereiakes, D.J., Ellis, S., Onuma, Y., et al. (2016) 1-Year Outcomes with the Absorb Bioresorbable Scaffold in Patients with Coronary Artery Disease: A Patient-Level, Pooled Meta-Analysis. The Lancet, 387, 1277-1289.

http://dx.doi.org/10.1016/S0140-6736(15)01039-9

[55] Banach, M., Serban, M.-C., Sahebkar, A., Garcia-Garcia, H.M., Mikkailidis, D.P., et al. (2016) Comparison of Clinical Outcomes between Bioresorbable Vascular Stents versus Conventional Drug-Eluting and Metallic Stents: A Systematic Review and Meta-Analysis. Journal of the American College of Cardiology, 67, 57. http://dx.doi.org/10.1016/S0735-1097(16)30058-4

[56] Zhang, X.-L., Zhu, L., Wei, Z.-H., Zhu, Q.-Q., Qiao, J.-Z., et al. (2016) Comparative Efficacy and Safety of Everolimus-Eluting Bioresorbable Scaffold versus Everolimus-Eluting Metallic Stents: A Systematic Review and Meta-Analysis. Annals of Internal Medicine, 164, 752-763. http://dx.doi.org/10.7326/M16-0006

[57] Markovic, S., Walcher, W.D., Bernhardt, P., Imhof, A., Rottbauer, W. and Wohrie, J. (2016) Clinical Results of Single and Multiple Bioresorbable Drug-Eluting Scaffolds for Treatment of De-Novo Coronary Artery Disease. Coronary Artery Disease, in press.

[58] Houde, M., Ince, H., Abizaid, A., Toelg, R., Lemos, P.A., et al. (2015) Safety and Performance of the Second-Generation Drug-Eluting Absorbable Metal Scaffold in Patients with De-Novo Coronary Artery Lesions (BIOSOLVE-II): 6 Month Results of a Prospective, Multicenter, Non-Randomised, First-in-Man Trial. The Lancet, 387, 31-39. http://dx.doi.org/10.1016/S0140-6736(15)00447-X

[59] Pandya, B., Gaddam, S., Raza, M., Asti, D., Nalluri, N., Vazzana, T., Kandov, R. and Lafferty, J. (2016) Biodegradable Polymer Stents vs Second Generation Drug Eluting Stents: A Meta-Analysis and Systematic Review of Randomized Controlled Trials. World Journal of Cardiology, 8, 240-246. http://dx.doi.org/10.4330/wjc.v8.i2.240

[60] Verheye, S., Ormiston, J.A., Stewart, J., Webster, M., Sanidas, E., et al. (2014) A Next- Generation Bioresorbable Coronary Scaffold System: From Bench to First Clinical Evaluation. JACC: Cardiovascular Interventions, 7, 89-99. http://dx.doi.org/10.1016/j.jcin.2013.07.007

[61] Di Mario, C. and Calazzo, G. (2015) Biodegradable Stents: The Golden Future of Angioplasty? The Lancet, 385, 10-12. http://dx.doi.org/10.1016/S0140-6736(14)61636-6

[62] Kalva, N.R. and Graumlich, J.F. (2016) Randomized Controlled Trials. In: Asche, C., Ed., Applying Competitive Effectiveness Data for Medical Decision Making, Springer International Publishing, Switzerland, 13-25. http://dx.doi.org/10.1007/978-3-319-23329-1 2

[63] Chen, Y., Xu, Z., Smith, C. and Sankar, J. (2014) Recent Advances on the Development of Magnesium Alloys for Biodegradable Implants. Acta Biomaterialia, 10, 4561-4573. http://dx.doi.org/10.1016/j.actbio.2014.07.005

[64] Cha, P.-R., Hon, H.-S., Yang, G.-F., Kim, Y.-C., Hong, K.-H., Lee, S.-C., Jung, J.-Y., Ahn, J.-P., Lim, Y.-Y., Cho, S.-Y., Byun, J.Y., Lee, K.-S., Yong, S.-J. and Seok, H.-K. (2013) Biodegradability Engineering of Biodegradable Mg Alloys: Tailoring the Electrochemical and Microstructure of Constituent Phases. Scientific Reports, 3, Article No. 2367. http://dx.doi.org/10.1038/srep02367

[65] Zhang, X., Wang, Q., Ba, Z., Wang, Z. and Xue, Y. (2016) Improved Corrosion Resistance of As-Extruded GZ51K Magnesium Alloy with High Mechanical Properties by Aging Treatment. Journal of Materials Engineering and Performance, 25, 719-725. http://dx.doi.org/10.1007/s11665-016-1941-7

[66] Gu, X., Zheng, W., Cheng, Y. and Zheng, Y. (2009) A Study on Alkaline Heat Treated Mg-Ca Alloy for the Control of the Biocorrosion Rate. Acta Biomaterialia, 5, 2790-2799. http://dx.doi.org/10.1016/j.actbio.2009.01.048 
[67] Liu, Z.L., Liu, Y., Liu, X.Q. and Wang, M.M. (2013) Effect of Minor Zn Additions on the Mechanical and Corrosion Properties of Solution-Treated AM60-2\%RE Magnesium Alloy. Journal of Materials Engineering and Performance, 25, 2855-2865. http://dx.doi.org/10.1007/s11665-016-2077-5

[68] Liu, C., Liang, J., Zhou, J., Wang, L. and Li, Q. (2015) Effect of Laser Surface Melting on Microstructure and Corrosion Characteristics of AM60B Magnesium Alloy. Applied Surface Science, 343, 133-140. http://dx.doi.org/10.1016/j.apsusc.2015.03.067

[69] Denkena, B. and Lucas, A. (2007) Biocompatible Magnesium Alloys as Absorbable Implant Materials-Adjusted Surface and Subsurface Properties by Machining Processes. CIRP Annals-Manufacturing Technology, 56, 113-116. http://dx.doi.org/10.1016/j.cirp.2007.05.029

[70] Pu, Z., Yang, S., Song, G.-L., Dillon Jr., O.W., Pulco, D.A. and Jawahir, L.S. (2011) Ultrafine-Grained Surface Layer on Mg-Al-Zn Alloy Produced by Cryogenic Burnishing for Enhanced Corrosion Resistance. Scripta Materialia, 65, 520-523.

http://dx.doi.org/10.1016/j.scriptamat.2011.06.013

[71] Kotoka, R., Yamaoh, N.K., Mensah-Darkoe, K., Moses, T. and Kumar, D. (2016) Electrochemical Corrosion Behavior of Silver Doped Tricalcium Phosphate Coatings on Magnesium for Biomedical Application. Surface and Coatings Technology, 292, 99-109. http://dx.doi.org/10.1016/j.surfcoat.2016.03.017

[72] Lin, D.-J., Hunga, F.-Y., Jakfar, S. and Yeh, M.-L. (2016) Tailored Coating Chemistry and Interfacial Properties for Construction of Bioactive Ceramic Coatings on Magnesium Biomaterial. Materials \& Design, 89, 235-244. http://dx.doi.org/10.1016/j.matdes.2015.09.144

[73] Liu, C., Xin, Y., Tian, X. and Chu, P.K. (2007) Corrosion Behavior of AZ91 Magnesium Alloy Treated by Plasma Immersion Ion Implantation and Deposition in Artificial Physiological fluids. Thin Solid Films, 516, 422-427. http://dx.doi.org/10.1016/j.tsf.2007.05.048

[74] Tian, Q. and Huinan L. (2015) Electrophoretic Deposition and Characterization of Nanocomposites and Nanoparticles on Magnesium Substrates. Nanotechnology, 26, Article No. 175102. http://dx.doi.org/10.1088/0957-4484/26/17/175102

[75] Iskandar, M.E., Aslani, A. and Liu, H. (2013) The Effects of Nanostructured Hydroxyapatite Coating on the Biodegradation and Cytocompatibility of Magnesium Implants. Journal of Biomedical Materials Research Part A, 101A, 2340-2354. http://dx.doi.org/10.1002/jbm.a.34530

[76] Abdal-hay, A., Dewidar, M., Lim, J. and Lim, J.K. (2014) Enhanced Biocorrosion Resistance of Surface Modified Magnesium Alloys Using Inorganic/Organic Composite Layer for Biomedical Applications. Ceramics International, 40, 2237-2247. http://dx.doi.org/10.1016/j.ceramint.2013.07.142

[77] Lin, B., Zhong, C., Zheng, C., Cao, L., Wang, D., Wang, L., Liang, J. and Cao, B. (2015) Preparation and Characterization of Dopamine-Induced Biomimetic Hydroxyapatite Coatings on the AZ31 Magnesium Alloy. Surface and Coatings Technology, 281, 82-88. http://dx.doi.org/10.1016/j.surfcoat.2015.09.033

[78] Mohajernia, S., Hejazi, S., Eslami, A. and Saremi, M. (2015) Modified Nanostructured Hydroxyapatite Coating to Control the Degradation of Magnesium Alloy AZ31 in Simulated Body Fluid. Surface and Coatings Technology, 263, 54-60.

http://dx.doi.org/10.1016/j.surfcoat.2014.12.059

[79] Rojaee, R., Fathi, M. and Raeissi, K. (2014) Comparing Nanostructured Hydroxyapatite Coating on AZ91 Alloy Samples via Sol-Gel and Electrophoretic Deposition for Biomedical Applications. IEEE Transactions on NanoBioscience, 13, 409-414. http://dx.doi.org/10.1109/TNB.2014.2338931 
[80] Surmeneva, M.A. and Surmenev, R.A. (2015) Microstructure Characterization and Corrosion Behavior of a Nano-Hydroxyapatite Coating Deposited on AZ31 Magnesium Alloy Using Radio Frequency Magnetron Sputtering. Vacuum, 117, 60-62.

http://dx.doi.org/10.1016/j.vacuum.2015.04.004

[81] Razavi, M., Fathi, M., Savabi, O., Razavi, S.M., Beni, B.H., Vashaee, D. and Tayebi, L. (2014) Controlling the Degradation Rate of Bioactive Magnesium Implants by Electrophoretic Deposition of Akermanite Coating. Ceramics International, 40, 3865-3872.

http://dx.doi.org/10.1016/j.ceramint.2013.08.027

[82] Rojaee, R., Fathi, M.H. and Raeissi, K. (2013) Electrophoretic Deposition of Nanostructured Hydroxyapatite Coating on AZ91 Magnesium Alloy Implants with Different Surface Treatments. Applied Surface Science, 285, 664-673. http://dx.doi.org/10.1016/j.apsusc.2013.08.108

[83] Diez, M., Kang, M.-H., Kim, S.-M. Kim, H.-E. and Song, J. (2016) Hydroxyapatite (HA)/ Poly-L-Lactic Acid (PLLA) Dual Coating on Magnesium Alloy Under Deformation for Biomedical Applications. Journal of Materials Science: Materials in Medicine, 27, 34. http://dx.doi.org/10.1007/s10856-015-5643-8

[84] Wang, H., Estrin, Y. and Zuberova, Z. (2008) Bio-Corrosion of a Magnesium Alloy with Different Processing Histories. Materials Letters, 62, 2476-2479. http://dx.doi.org/10.1016/j.matlet.2007.12.052

[85] Ralston, J.D., Birbilis, N. and Davies, C.H. (2010) Revealing the Relationship between Grain Size and Corrosion Rate of Metals. Scripta Materialia, 63, 1201-1204. http://dx.doi.org/10.1016/j.scriptamat.2010.08.035

[86] Fare, S., Ge, Q.A., Vedani, M., Vimercati, G., Gastaldi, D., et al. (2010) Evaluation of Material Properties and Design Requirements for Biodegradable Magnesium Stents. Matéria (Rio de Janeiro), 15, 103-112. http://dx.doi.org/10.1590/s1517-70762010000200002

[87] Khalajabadi, S.Z., Kadir, M.R.A., Izman, S. and Ebrahimi-Kahrizsangi, R. (2015) Fabrication, Bio-Corrosion Behavior and Mechanical Properties of a Mg/HA/MgO Nanocomposite for Biomedical Applications. Materials \& Design, 88, 1223-1233. http://dx.doi.org/10.1016/j.matdes.2015.09.065

[88] Salahshoor, M. and Gao, Y.B. (2013) Process Mechanics in Ball Burnishing Biomedical Magnesium-Calcium Alloy. The International Journal of Advanced Manufacturing Technology, 64, 133-144. http://dx.doi.org/10.1007/s00170-012-4024-4

[89] Zhang, X.B., Zhang, Y., Chen, K., Bai, Z.X., Wang, Z.Z. and Wang, Q. (2015) Microstructure, Mechanical and Corrosion Properties of Mg-Nd-Zn-Sr-Zr Alloys as a Biodegradable Material. Materials Science and Technology, 31, 866-873. http://dx.doi.org/10.1179/1743284714Y.0000000661

[90] Mareci, D., Izquiierdo, J., Crimu, C., Munteanu, C., Antoniac, I. and Souto, R.M. (2016) Electrochemical Characteristics of Bioresorbable Binary MgCa Alloys in Ringer's Solution: Revealing the Impact of Local pH Distributions during In-Vitro Dissolution. Materials Science and Engineering: C, 60, 402-410. http://dx.doi.org/10.1016/j.msec.2015.11.069

[91] Hahn, B.-D., Park, D.-S., Choi, J.-J., Ryu, J., Yoon, W.-H., Kim, K.-H., Park, C. and Kim, H.-E. (2009) Dense Nanostructured Hydroxyapatite Coating on Titanium by Aerosol Deposition. Journal of the American Ceramic Society, 92, 683-687. http://dx.doi.org/10.1111/j.1551-2916.2008.02876.x

[92] Hahn, B.D., Lee, J.M., Park, D.S., Choi, J.J., Ryu, J., Yoon, W.H., Choi, J.H., Lee, B.K., Kim, J.W., Kim, H.E. and Kim, S.G. (2011) Enhanced Bioactivity and Biocompatibility of Nanostructured Hydroxyapatite Coating by Hydrothermal Annealing. Thin Solid Films, 519, 8085-8090. http://dx.doi.org/10.1016/j.tsf.2011.07.008 
[93] Li, X., Huang, J., Ahmad, Z. and Edirisinghe, M. (2007) Electrohydrodynamic Coating of Metal with Nano-Sized Hydroxyapatite. Bio-Medical Materials and Engineering, 17, 335346.

[94] Huang, Y., Song, L., Huang, T., Liu, X., Xiao, Y., Wu, Y., Wu, F. and Gu, Z. (2010) Characterization and Formation Mechanism of Nano-Structured Hydroxyapatite Coatings Deposited by the Liquid Precursor Plasma Spraying Process. Biomedical Materials, 5, Article ID: 054113. http://dx.doi.org/10.1088/1748-6041/5/5/054113

[95] Amirudin, A. and Thieny, D. (1996) Application of Electrochemical Impedance Spectroscopy to Study the Degradation of Polymer-Coated Metals. Progress in Organic Coatings, 26, 1-28. http://dx.doi.org/10.1016/0300-9440(95)00581-1

[96] Chen, L.-Y., Xu, J.-Q., Choi, H., Pozuelo, M., Ma, Y., Bhominck, S., Yang, J.-M., Mathaudhu, S. and Li, X.-C. (2015) Processing and Properties of Magnesium Containing a Dense Uniform Dispersion of Nanoparticles. Nature, 528, 539-543.

http://dx.doi.org/10.1038/nature16445

[97] Nagura, H. (2014) Intravascular Implants. Teruma Kabushiki Kaisha, Tokyo.

[98] Herzog, D., Seyda, V., Wycisk, E. and Emmelmann, C. (2016) Additive Manufacturing of Metals. Acta Materialia, 117, 371-392. http://dx.doi.org/10.1016/j.actamat.2016.07.019

[99] Lewandowski, J.J. and Seifi, M. (2016) Metal Additive Manufacturing: A Review of Mechanical Processes. Annual Review of Materials Research, 46, 151-186.

http://dx.doi.org/10.1146/annurev-matsci-070115-032024

[100] Sing, S.L., An, J., Yeong, W.Y. and Wiria, F.E. (2016) Laser and Electron-Beam Powder-Bed Additive Manufacturing of Metallic Implants: A Review on Processes, Materials and Designs. Journal of Orthopaedic Research, 34, 369-385. http://dx.doi.org/10.1002/jor.23075

[101] ASTM (2013) Standard F2792: Standard Terminology for Additive Manufacturing Technologies.

[102] Gao, W., Zhang, Y., Ramanujan, D., Ramani, K., Chen, Y., Williams, C.B., Wang, C.C.L., Shin, Y.C., Zhang, S. and Zavattieri, P.D. (2015) The Status, Challenges, and Future of Additive Manufacturing in Engineering. Computer-Aided Design, 69, 65-89.

http://dx.doi.org/10.1016/j.cad.2015.04.001

[103] Takemoto, M., Fujihayashi, S., Ota, E., Otsuki, B., Kimura, H., Sakamoto, T., Kawaai, T., Futami, T., Sasaki, K., Matsushita, T., Nakamura, T., Neo, M. and Matsuda, S. (2016) Additive-Manufactured Patient-Specific Titanium Templates for Thoracic Pedicle Screw Placement: Novel Design with Reduced Contact Area. European Spine Journal, 25, 1698-1705. http://dx.doi.org/10.1007/s00586-015-3908-Z

[104] Singare, S., Lio, Y., Li, D., Wang, J. and He, S. (2008) Individually Prefabricated Prosthesis for Maxilla Reconstruction. Journal of Prosthodontics, 17, 135-140.

[105] Zopf, D.A.S., Hollister, S.J., Nelson, M.E., Obye, R.G. and Green, G.E. (2013) Bioresorbable Airway Splint Created with a Three-Dimensional Printer. The New England Journal of Medicine, 368, 2043-2045. http://dx.doi.org/10.1056/NEJMc1206319

[106] Moore, S.S., O’Sullivan, K.J. and Verdecchia, F. (2016) Shrinking the Supply Chain for Implantable Coronary Stent Devices. Annals of Biomedical Engineering, 44, 497-507. http://dx.doi.org/10.1007/s10439-015-1471-8

[107] Tapa, G., Elwamy, A.H. and Sang, H. (2016) Prediction of Porosity in Metal-Based Additive Manufacturing Using Spatial Gaussian Process Models. Additive Manufacturing, in press. http://dx.doi.org/10.1016/j.addma.2016.05.009 
Submit or recommend next manuscript to SCIRP and we will provide best service for you:

Accepting pre-submission inquiries through Email, Facebook, LinkedIn, Twitter, etc. A wide selection of journals (inclusive of 9 subjects, more than 200 journals)

Providing 24-hour high-quality service

User-friendly online submission system

Fair and swift peer-review system

Efficient typesetting and proofreading procedure

Display of the result of downloads and visits, as well as the number of cited articles

Maximum dissemination of your research work

Submit your manuscript at: http://papersubmission.scirp.org/

Or contact wjet@scirp.org 